\title{
Contribution to the pteridophytic flora of India: Nokrek Biosphere Reserve, Meghalaya
}

\author{
Bikarma Singh ${ }^{1}$, V.N. Singh ${ }^{2}$, S.J. Phukan ${ }^{3}$, B.K. Sinha ${ }^{4}$ \& S.K. Borthakur ${ }^{5}$ \\ 1,2,3,4 Botanical Survey of India, Eastern Circle, Shillong, Meghalaya 793002, India \\ ${ }^{5}$ Department of Botany, Gauhati University, Gawhati, Assam 781014, India \\ Email: ${ }^{1}$ bikarmasinghtaxonomy@gmail.com (corresponding author), ${ }^{2}$ always_vivek@rediffmail.com, ${ }^{3}$ drsphukan@gmail.com \\ ${ }^{4}$ drbks2004@yahoo.co.in, ${ }^{5}$ skbgu1@gmail.com
}

Date of publication (online): 26 January 2012 Date of publication (print): 26 January 2012 ISSN 0974-7907 (online) | 0974-7893 (print)

Editor: M.K. Vasudeva Rao

\section{Manuscript details:}

Ms \# 02751

Received 05 April 2011

Final received 05 August 2011

Finally accepted 23 December 2011

Citation: Singh, B., V.N. Singh, S.J. Phukan, B.K Sinha \& S.K. Borthakur (2012). Contribution to the pteridophytic flora of India: Nokrek Biosphere Reserve, Meghalaya. Journal of Threatened Taxa 3(12): 2277-2294.

Copyright: (C) Bikarma Singh, V.N. Singh, S.J. Phukan, B.K. Sinha \& S.K. Borthakur 2012. Creative Commons Attribution 3.0 Unported License. JoTT allows unrestricted use of this article in any medium for non-profit purposes, reproduction and distribution by providing adequate credit to the authors and the source of publication.

For Author Details and Author Contribution: see end of this article.

Acknowledgements: The first author is thankful to the Ministry of Environment and Forests, Government of India, New Delhi for financial assistance in the form of Senior Research Fellowship. The authors are thankful to Dr. M. Sanjapp, Director of Botanical Survey of India, Kolkata, India for providing necessary facilities, and also kindly acknowledged to Dr. C.R. Fraser-Jenkins, Research Associate, Royal Botanic Garden, Edinburgh, Scotland for his help in identification of some rare pteridophytes during his visit to Shillong Assam herbarium. Authors are also thankful to the staff members of the Meghalaya Forest Department of the Nokrek region for extending support during our field study.
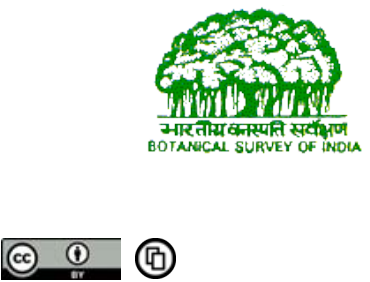

OPEN ACCESS | FREE DOWNLOAD
Abstract: Nokrek National Park, located approximately 40km from Tura town in West Garo Hills district of Meghalaya, India, was added to the list of Biosphere Reserves by UNESCO in May 2009. Since there is no previous report from this area, the pteridophytes of the Nokrek Biosphere Reserve are catalogued in the present study. The checklist consists of 113 taxa (98 ferns, 15 fern allies), of which 25 species are newly reported for the Meghalaya State (Selaginella involvens, Selaginella semicordata, Selaginella subdiaphana, Selaginella tenuifolia, Asplenium gueinzianum, Asplenium perakanse, Microlepia hancei, Microlepia rhomboidea, Dicranopteris linearis, Coniogramme procera, Bolbitis sinensis, Loxogramme chinensis, Lygodium microphyllum, Lemmaphyllum microphyllum, Lemmaphyllum rostratum, Pleopeltis macrosphaera, Pyrrosia lanceolata, Pyrrosia longifolia, Pteris biaurita ssp. walkeriana, Pteris grevilleana, Tectaria fuscipes, Cyclosorus crinipes, Pseudocyclosorus falcilobus, Diplazium apicisorum and Diplazium pseudosetigerum) and 43 species are new for all the three Garo Hill districts of the Garo Hills in the Meghalaya State.

Keywords: Eastern Himalayas, India, Nokrek Biosphere Reserve, pteridophyte flora.

\section{INTRODUCTION}

Nokrek National Park or Nokrek Biosphere Reserve is a national park located approximately $40 \mathrm{~km}$ from Tura Peak in West Garo Hills District of Meghalaya, India. UNESCO added this national park to its list of biosphere reserves in May 2009. The Nokrek range of hills situated at the eastern-most tip of the eastern Himalaya is notable for its very rich and diverse luxuriant vegetation, dotted with a high concentration of endemics as well as rare, endangered and threatened plants. It is considered to be a gene pool of Citrus species in the northeastern states of India, and the cultural meeting point of three Garo districts of Meghalaya State; rich in myths, folk traditional knowledge, biodiversity and associated cultural tribal practices. These Garo Hills form the major peaks (Nokrek Peak and Tura Peak), towards the tail end of Assam, before they abruptly fall into the low hills of Bangladesh. This is a compact range of hills with the main range descending equally steeply to all the three Garo districts of Meghalaya. The dense forests of these hills provide a home for many narrow endemics of phytogeographical significance, such as Vanda coerulea Griff. ex Lindl., Nepenthes khasiana Hook.f. and Citrus indica Tanaka species. Considering the immense need for conservation, the area is protected as a biosphere reserve since 1988. The angiosperm flora of the area has largely been explored by the Botanical Survey of India, Eastern Circle, Shillong which recorded more than 1000 species, the herbarium specimens are housed in Assam. Of these more than 51 are endemics 
and 57 species belong to various threat categories as revealed in the literature, viz., IUCN (1966), Baishya \& Rao (1982), Kataki (1982), Chauhan (1983), Datta (1983), Das \& Deori (1983), Haridasan \& Rao (1984, 1985-87), Nayar (1980, 1996), Jagtap \& Singh (1999), Chowdhery \& Murti (2000), Olson (2001) and Singh \& Panigrahi (2005). However, no effort was done earlier to study the pteridophyte diversity in this rich biosphere reserve.

\section{MATERIALS AND METHODS}

\section{Study area}

The Nokrek proper, with its northern and western slopes, forms a compact block of hilly ranges towards the northern and western end of the Garo Hills and belongs to the three Garo districts of Meghalaya State; the southern slope falls into the plains of Bangladesh. The area is believed to be the abode of the Garo tribal community, belonging to the Tibeto-Chinese family of the Tibeto-Burman subfamily of the Bodo group, who live in about 132 villages situated in and around Nokrek (Tripathi et al. 2008). The people have conserved some forest patches as 'sacred groves' and thus this hilly area is considered sacred, and a symbol of conservation with deep cultural imprints of traditional beliefs. Topographically, the area steeply descends from all sides of the highest peak the Nokrek Peak, with an altitude of $1412 \mathrm{~m}$. A major portion of the area belongs to the Nokrek National Park and Citrus Wildlife Sanctuary, and the rest is in the reserved forests of the Garo wildlife forest division. The IUCN has identified Nokrek and its environs to be one of the three centers of plant diversity within India, and focused on the need for immediate conservation (IUCN 1987). The Nokrek Biosphere Reserve was also internationally recognized within the framework of UNESCO's Man and Biosphere (MAB) programme in 2009 .

The temperature varies from $9.5-37.3{ }^{\circ} \mathrm{C}$, typical of Assam, March-May being the hottest and December-February being the coolest months. Both south-west and northeastern monsoons bring rain to the area ranging from 3900 to $6800 \mathrm{~mm} /$ year. The soil is mainly red loamy and the area is drained by several perennial streams, which collect to form one major river system viz., Brahmaputra. The great diversity in ecological features and the high range of altitudinal variation are responsible for the very rich and diverse vegetation of the area. It belongs to the Indo-Malayan eco-region (Olson et al. 2001) with the major vegetation type: tropical forests $(200-900 \mathrm{~m})$ and subtropical forests (900-1412 m). The soil is very shallow and vegetation becomes active mainly after the monsoons and may dry up in the southern slopes during the dry season. There is a clear demarcation of vegetation types based on the altitudinal range. The

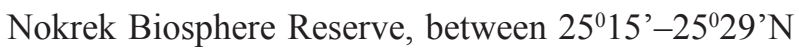
and $90^{\circ} 13^{\prime}-90^{\circ} 30^{\prime} \mathrm{E}$, was established on 13 September 1988 (vide Govt. of India, MoEF Order No. 27/59/81C5 dt. 13 September 1988) with an area of about $8,20 \mathrm{~km}^{2}$, of which $47.48 \mathrm{~km}^{2}$ (vide Govt. of Meghalaya Notification No. FOR.23/86/316 dated 23.10.1997) is the core area (Fig. 1). The NBR straddles the border of Assam State and Bangladesh. It is composed of Citrus Gene Pool Sanctuary and Mahseer Hatchery Centre and their adjoining areas of Hallaidang, Daihadubi, Darugiri and Rongrengiri ranges of Garo Hills Forest Divisions. It is the habitat of many varieties of medicinal plants, wild edible plants and plants of other economic importance (Images $1 \& 2$ ). The area is equally rich in faunal elements also with a large number of birds, butterflies, amphibians and reptiles. The rare mammals of the area include the Hoolock Gibbon, Asian Elephant, Gaur, Leopard, Sambar, Barking Deer, Malayan Bear, Assamese Macaque, Rhesus Macaque, Giant Squirrel, Slow Loris, Himalayan Palm Squirrel, Hare, etc. The Nokrek is also notable for being the home of the Garos, one of the hilly tribes, who have a thorough knowledge of the local biodiversity, its utilization potentials and with many cultural practices unique to them. According to the Garos of Nokrek, there is also a mammal locally called Badamanu-big feet man, in the core area, but not evidenced.

The pteridophyte specimens were collected from 2006 to 2010 and deposited in Assam Herbarium at the Botanical Survey of India, Eastern Circle, Shillong. The families are arranged alphabetically. Each species is listed with author citation (Brummitt \& Powell 1992) followed by the field observations on the habitat on which it was found growing in the study area, the locality, altitude, the collector's name (acronyms: BS - Bikarma Singh; VNS - V.N. Singh; BKS - B.K. Sinha; DBD - D.B. Deb; RS = R. Shanpru; GP - G. Panigrahi; MKVR - M.K.V. Rao), collection number, 


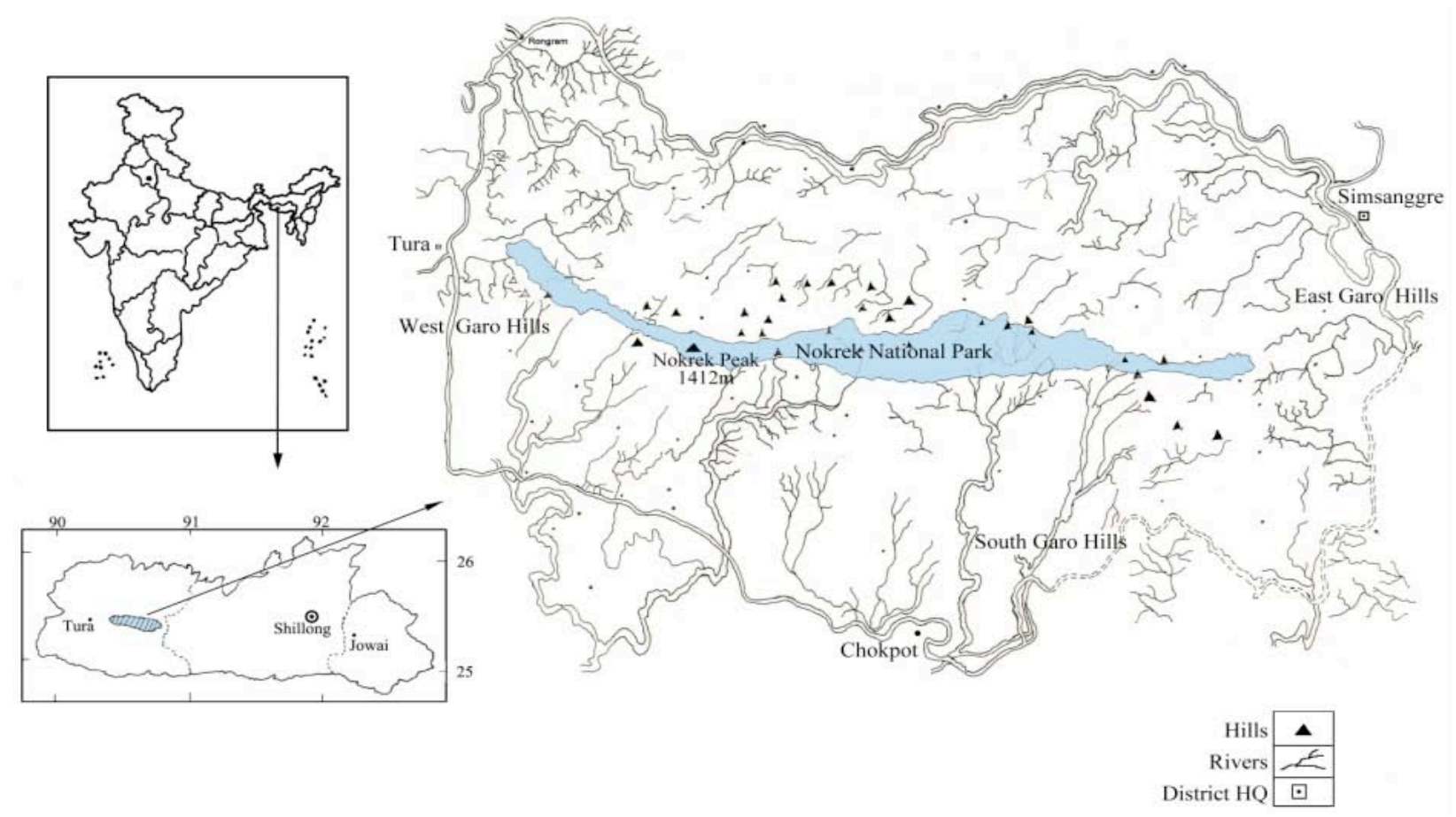

Figure 1. Location map of Nokrek Bioshere Reserve in India

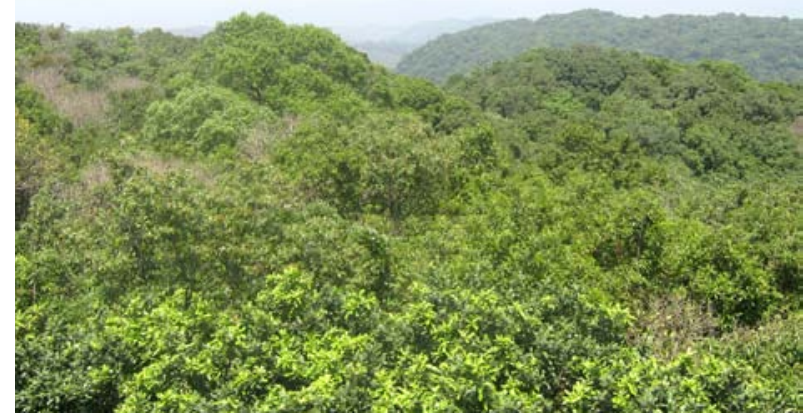

Image 1. Core area of Nokrek Biosphere Reserve

\section{RESULTS}

\section{Fern-allies}

\section{Equisetaceae}

Equisetum diffusum D. Don. (Image 3): Terrestrial near the river in sandy loamy soil. Near river Didari from Daribogre (963m), VNS \& BS 114552 (Assam). Although this species is very common in Nokrek, it is a new record for the Garo District. It is widely

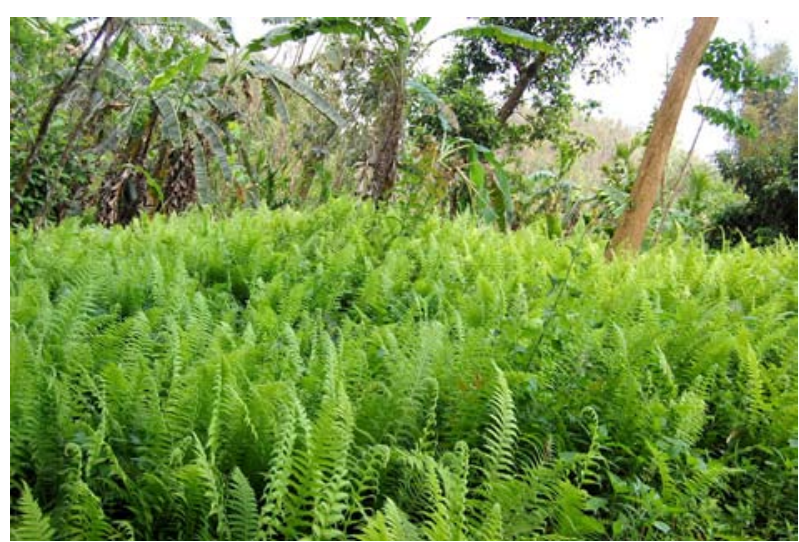

Image 2. View of Luxurient growth of pteridophyte in Nokrek

distributed in India (Arunachal Pradesh, Assam, Andaman Islands, Meghalaya, Kerala, Sikkim, Tamil Nadu), Bangladesh, China, Myanmar, Nepal and Sri Lanka.

Equisetum ramosissimum Desf. subsp. debile (Roxb. ex DC.) Hauke: Terrestrial near the river in sandy loamy soil. Rongsingiri (350m), VNS \& BS 115886 (Assam). It is rare in Nokrek, and recorded only from Rongsingiri Village in this biosphere reserve. It is distributed in northeastern India (Arunachal Pradesh, Assam, Meghalaya), Bangladesh, China and Nepal. 


\section{Huperziaceae}

Huperzia hamiltonii (Spreng) Trev.: Epiphyte on rotten tree trunks in shady and wet places. Nokrek Peak (1150m), VNS \& BS 114711 (Assam). Rare in high altitude areas of Nokrek. Widely distributed in India (Arunachal Pradesh, Sikkim, Assam, Andaman Islands, Meghalaya, Kerala, Tamil Nadu), Australia, China, Malaysia, Myanmar, New Zealand and Sri Lanka.

Huperzia phlegmaria (L.) Rothm. (Image 4): On moss deposits on tree trunks in wet places. Nokrek Peak (1312m), VNS \& BS 118573 (Assam). This species is rare in Nokrek, and is also very rare in Meghalaya State (Baishya \& Rao 1982). Chandra et al. (2008) considered this species under the rare category. This species is distributed in India (Andaman Islands, Arunachal Pradesh, Assam, Kerala, Meghalaya, Sikkim, West Bengal), Australia, Bhutan, Myanmar and New Zealand.

\section{Lycopodiaceae}

Palhinhaea cernua (L.) A. Franco. \& Vasc.: Epiphytic on decaying tree trunks in moist places. Way to Khalakgre (1062m) VNS \& BS 114765 (Assam). It is very common in Nokrek, and distributed widely in northeastern India (Arunachal Pradesh, Assam, Meghalaya, Sikkim), southern India (Kerala, Karnataka), Australia, China, Nepal, Myanmar, New Zealand and Sri Lanka.

\section{Selaginellaceae}

Selaginella decipiens Warb. (Image 5): Terrestrial in wet places. Way to Nokrek Peak (1200m), VNS \& BS 114762 (Assam). Occasionally found growing in the dense forests of Nokrek, and recorded for the first time in Garo Hill District. It is distributed in northeastern India (Sikkim, Darjeeling, Meghalaya, Manipur), southern India (Tamil Nadu, Kerala), Nepal, Myanmar, Thailand and Vietnam.

Selaginella delicatula Alston.: Terrestrial in wet places. Way to Daribokgre (782m) BS \& VNS 115837 (Assam). Very common in Nokrek. It is widely distributed in northeastern India (Assam, Arunachal Pradesh, Meghalaya), China, Nepal and Myanmar.

Selaginella helferi Warb.: Terrestrial in wet places in dense forests. Way to Chandigre $(512 \mathrm{~m})$ VNS \& BS s.n. (Assam 74674). Very common in Nokrek. This species is distributed in India (Assam, Kerala,

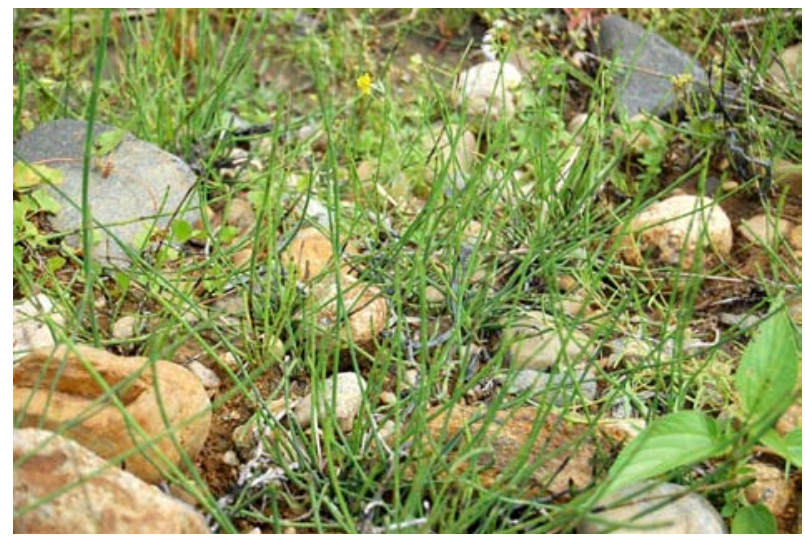

Image 3. Equisetum diffusum

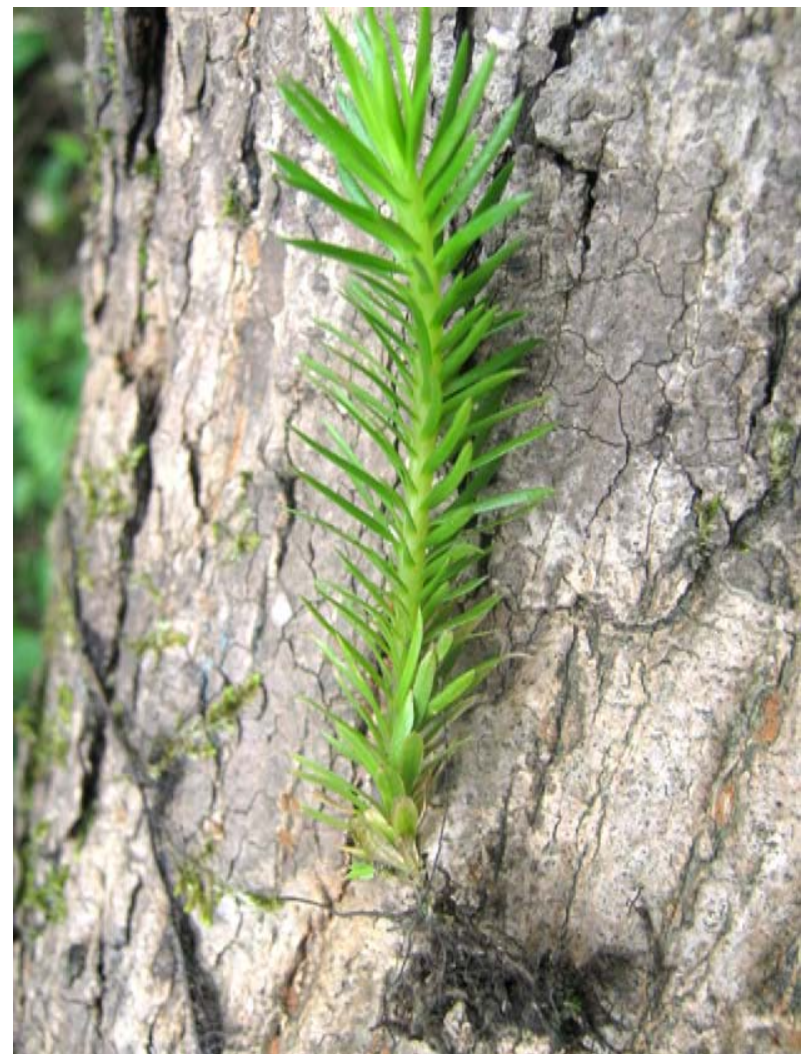

Image 4. Huperzia phlegmaria

Meghalaya, Sikkim, Tamil Nadu), Bangladesh, China, Nepal, Myanmar and Sri Lanka.

Selaginella hookeri Baker: Terrestrial in moist places. Daribokgre (809m) VNS \& BS 114759A (Assam). The species is recorded only from Daribokgre and is a new record for the Garo District. It is widely distributed in northeastern India (Arunachal Pradesh, Assam, Meghalaya, Nagaland), Bangladesh, China and Nepal.

Selaginella involvens (Sw.) Spring. Terrestrial as 


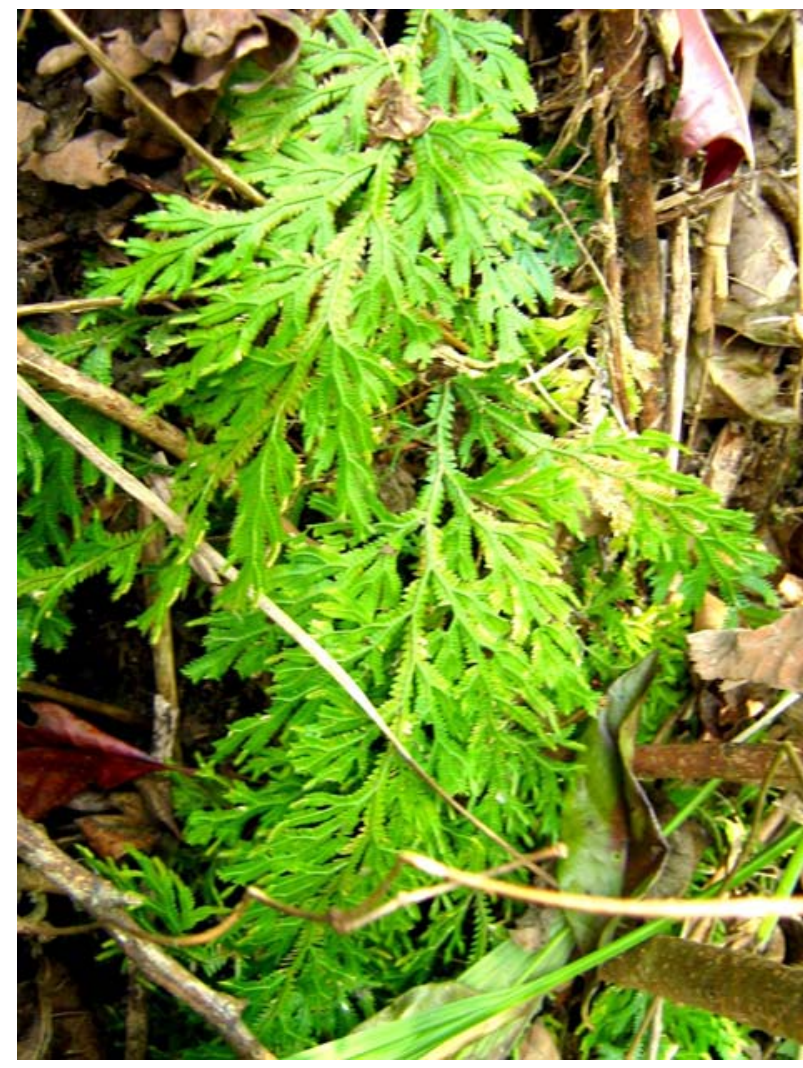

Image 5. Selaginella decipiens

well as lithophytic in wet places. Niengalmandalgre to Simsanggre (300-950 m) VNS \& BS 116894 (Assam), Tura Peak (850m) DBD 28914 (Assam). It is recorded to be rare in Nokrek, and is a new record for Meghalaya, although it was collected by Deb as cited above and deposited in Assam herbarium, but remained unidentified. This species is distributed in India (Assam, Meghalaya), China, Myanmar and Sri Lanka.

Selaginella monospora Spring. (Image 6): Terrestrial in moist places. Nokrek Peak (500-1412 m) VNS \& BS 114695 (Assam). Although this species is very common in all parts of Nokrek, no publications from the study site state so, hence it is a new record. It is widely distributed in northeastern India (Arunachal Pradesh, Assam, Manipur, Mizoram), southern India (Kerala, Tamil Nadu, Karnataka), Bangladesh, China, Nepal and Myanmar.

Selaginella semicordata (Wall. ex Hook. \& Grev.) Spring.: Terrestrial as well as lithophytic on moss laden rocks in moist places. Along Simsang River (652m) VNS \& BS 114659 (Assam). It is rare in Nokrek and reported for the first time from Meghalaya. The species is distributed in northeastern India, China and

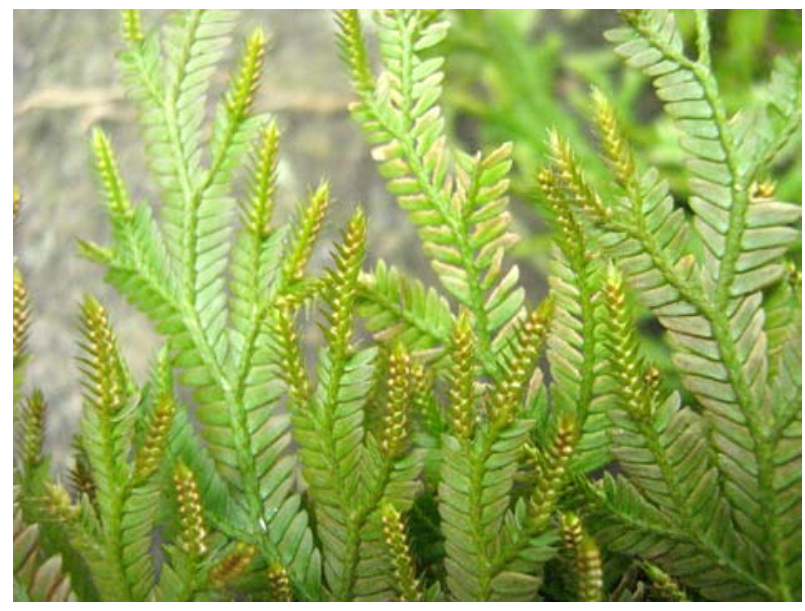

Image 6. Selaginella monospora

Nepal.

Selaginella subdiaphana Spring.: Terrestrial as well as epiphytic in dense forests. Tura Peak $(750 \mathrm{~m})$ DBD 28965 (Assam). Although this species was collected by Deb and housed in Assam herbarium, no publication from Meghalaya includes it; hence a new record for the state. It is widely distributed in northeastern India, Bangladesh and Nepal.

Selaginella tenuifolia Spring.: Epiphytic in dense forests. Nokrek Peak (1378m) VNS \& BS 118482B (Assam). It is rare in Nokrek, and recorded for the first time from Meghalaya. Chandra et al. (2008) considered this species rare and a threatened group pteridophyte. The species is distributed in northeastern India (Arunachal Pradesh, Meghalaya, Sikkim), eastern India (West Bengal, Darjeeling).

Selaginella wallichii (Hook. \& Grev.) Spring.: Terrestrial in dense forests along the sides of streams and rivers. Niengmandalgre to Simsangre (400-850 m) VNS \& BS 116894 (Assam). It is rare in Nokrek, but widely distributed in other parts of Meghalaya. It is distributed in Bangladesh, Nepal and Sri Lanka.

\section{Ferns}

\section{Adiantaceae}

Adiantum philippense L. (Image 7): On walls and on tree trunks in shady places. Tura forests $(650 \mathrm{~m})$ VNS \& BS 118314 (Assam). Common in Nokrek, and widely distributed in northeastern India (Arunachal Pradesh, Meghalaya), Bangladesh, Nepal and Taiwan.

\section{Aspleniaceae}

Asplenium cheilosorum Kunze ex Mett.: Terrestrial 
as well as epiphytic in moist and shady damp places. Nokrek Peak (1214m) VNS \& BS 114709 (Assam). The species is rare in Nokrek, and recorded for the first time from the Garo Hill District. It is widely distributed in south India (Kerala), northeastern India (Assam, Arunachal Pradesh, Meghalaya), Bhutan, China, Japan, Malaysia, Myanmar, Philippines, Sri Lanka, Taiwan and Vietnam.

Asplenium ensiforme Wall. ex Hook. \& Grev.: Epiphytic on moss covered tree trunks in dense forest. Dribokgre toward east (800m) VNS \& BS 114598 (Assam). It is rare in Nokrek and recorded only from the eastern part of NBR. A new record for the Garo Hill District, but widely distributed throughout hilly areas of India (Himalaya, Nilgiri Hills), Bhutan, China, Hong Kong, Japan, Myanmar, Nepal, Sri Lanka, Thailand and Vietnam.

Asplenium finlaysonianum Wall. ex Hook.: Epiphytic on decaying tree trunks. Ringrey $(500 \mathrm{~m})$ VNS \& BS 118391 (Assam). Occasionally in Nokrek, and recorded for the first time from the Garo District. Widely distributed in northeastern India (Assam, Arunachal Pradesh, Meghalaya, Nagaland), Bangladesh and Myanmar.

Asplenium gueinzianum Mett. ex Kuhn.: Epiphytic on moss covered tree trunks. Way to Tura Peak $(900 \mathrm{~m})$ MKV Rao 64379 (Assam). This species is rare in Nokrek, and recorded only from Tura Peak during the field tours. It is a new record for Meghalaya, and distributed in northeastern India (Arunachal Pradesh, Meghalaya and Nagaland), Bhutan, Japan and Taiwan.

Asplenium nidus L. (Image 8): Epiphytic as well as

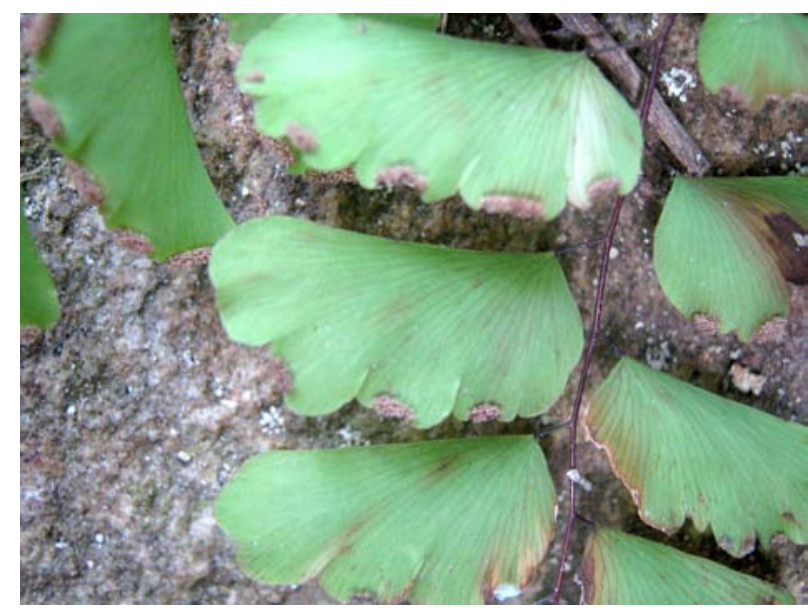

Image 7. Adiantum philippense lithophytic on moss covered tree trunks and on rocks. Near Khalakgre Nillage (990m) VNS \& BS 114546 (Assam). Although this species is very common in Nokrek and a new record for the Garo District. Widely distributed throughout hilly regions of northern India (Punjab, Kashmir, Delhi), and throughout all the districts of northeastern India, Africa, Bhutan, Madagascar, Malaya, Nepal, Polynesia, Philippines, Sri Lanka and Taiwan.

Asplenium normale D. Don.: Terrestrial as well as epiphytic in damp and moist places inside dense forest. Nokrek Peak (1306m) VNS \& BS 114672 (Assam). Very common in Nokrek and a new record for the Garo District. It is widely distributed in the hilly regions of southern India (Kerala, Tamil Nadu), northeastern India (Assam, Arunachal Pradesh, Meghalaya, Manipur), Africa, Bhutan, Hong Kong, Malaya, Nepal, Philippines, Polynesia, Sri Lanka and Taiwan.

Asplenium perakense Mattew \& C. Chr.: Epiphytic on moss covered tree trunks in dense forests. Way to Tura Peak (850m) MKVR 59418 (Assam). Very rare in Nokrek, and recorded for the first time from Meghalaya. It is distributed in India (Nagaland, Meghalaya, Myanmar, China, Japan and Vietnam.

Asplenium phyllitidis D. Don. (Image 9): Epiphytic as well as lithophytic on moss covered tree trunks and on rocks. Way to Rongsingiri $(400-500 \mathrm{~m})$ BS \& VNS 118294 (Assam). Common in the southern areas of Nokrek Reserve, but very rare in the eastern and western sides. Although this species is common in dense forests, it is a new record for the district. Widely distributed in India (Andaman Islands, Arunachal Pradesh, Meghalaya, Assam, Manipur), Myanmar,

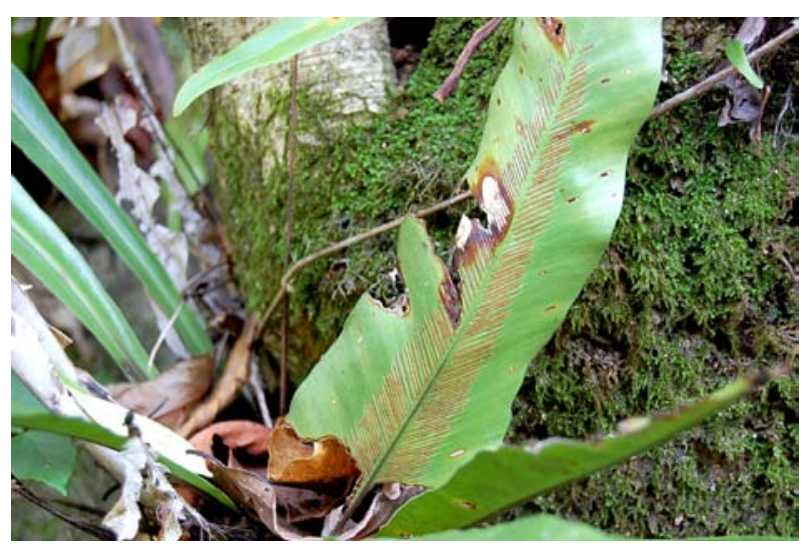

Image 8. Asplenium nidus 
Thailand, Malesia and Vietnam.

Asplenium unilaterale Lam.: Epiphytic on moss covered tree trunks near the sides of streams and river. Tura Peak (670m) GP 22463 (Assam). Very common in Nokrek, and widely distributed throughout Himalayan regions of India; Africa, China, Japan, Myanmar, Philippines, Polynesia, Sri Lanka and Taiwan.

\section{Blechnaceae}

Blechnum orientale L.: Terrestrial in open places. Bandari Falls (300m) VNS \& BS 114980 (Assam). The species is common in Nokrek and a new record for the Garo District. It is widely distributed in temperate Asia (China, Japan, Taiwan), tropical Asia in the Indian subcontinent (India, Nepal, Sri Lanka), Indo-China (Cambodia, Laos, Myanmar, Thailand, Vietnam), Malesia (Indonesia, Malaysia, Philippines), Australia and Pacific Islands.

\section{Cryptogrammaceae}

Onychium siliculosum (Desv.) C.Chr. (Image 10): Terrestrial in open places. Niengmandalgre (350-700 m) VNS \& BS 116840 (Assam). Very common in Nokrek, abundantly growing in lower elevation areas of Meghalaya. It is distributed in northeastern India (Assam, Arunachal Pradesh, Meghalaya), China, Japan and southern Malaya.

\section{Cyatheaceae}

Alsophila gigantea Wall. ex Hook. (Image 11): Terrestrial along river sides as well as in open places. Kalupara (500m) BS \& VNS 118460 (Assam). It is common in the southern side of Nokrek, but extremely rare in the eastern and western regions. It is a new

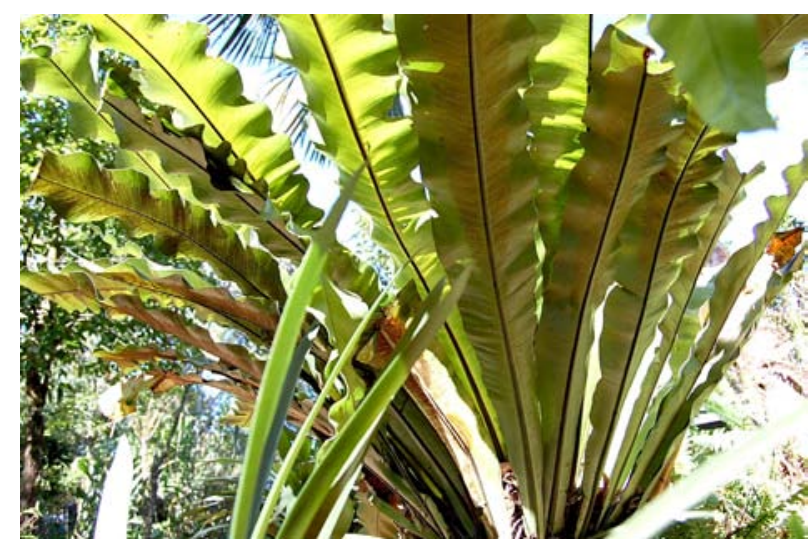

Image 9. Asplenium phyllitidis record for the Garo Hill districts. This species is widely distributed in the Himalayan regions of India, Bangladesh, China, Loas, Myanmar, Nepal, Sri Lanka, Thailand and Vietnam.

Alsophila khasyana T. Moore ex Kuhn. (Image 12): Terrestrial in moist and shady forests. Kalupara $6^{\text {th }}$ Mile area $(800 \mathrm{~m})$ VNS \& BS 118460 (Assam). This species is extremely rare in Nokrek, and is a new record for the Garo Hill District.. It is distributed in India (Western Ghats, eastern States of the Himalayas including Khasi Hills and Garo Hills of Meghalaya), Myanmar.

Alsophila spinulosa (Wall. ex Hook.) Tryon.: Terrestrial in moist and shady places along rivers and streams. Rongrengiri (350-600 m) VNS \& BS 114924 (Assam). This is rare in Nokrek, but widely distributed throughout the hilly areas of east Khasi Hills and west Garo Hills and a new record for the entire three Garo Hill districts. It is distributed in northeastern India, Bhutan, China, Japan, Myanmar, Nepal, Thailand and Taiwan.

\section{Davalliaceae}

Davallia griffithiana Hook. (Image 13): Epiphytic on moss laden tree trunks in dense forests. Way to Rongsengiri (500m) BS \& VNS 118293 (Assam). This is very rare in Nokrek, and recorded for the first time from Garo Hill District. This species is distributed in northeastern India (Arunachal Pradesh, Meghalaya, Nagaland), Bhutan, China, Myanmar and Taiwan.

Davallia trichomanoides Blume.: Epiphytic in dense forests. Rongsingiri (370m) VNS \& BS $115892 \mathrm{~b}$ (Assam). This species is common in Nokrek, (eastern

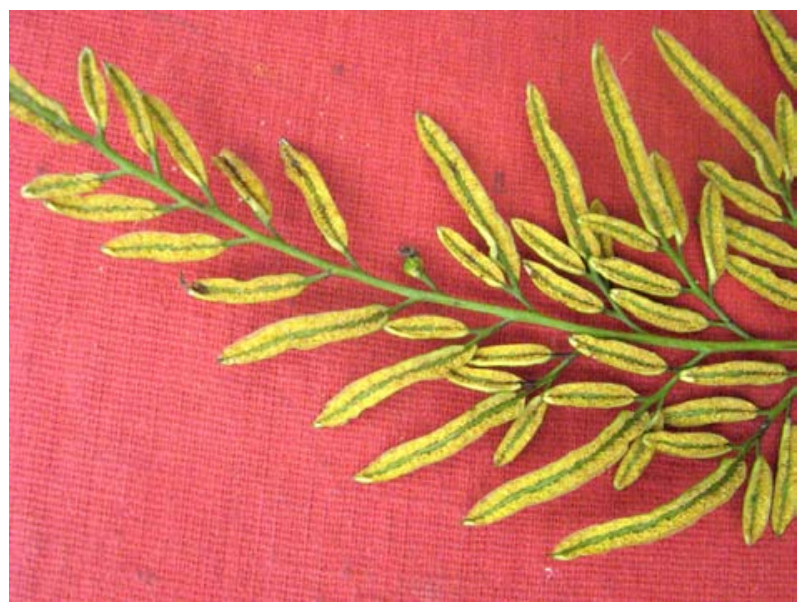

Image 10. Onychium siliculosum 


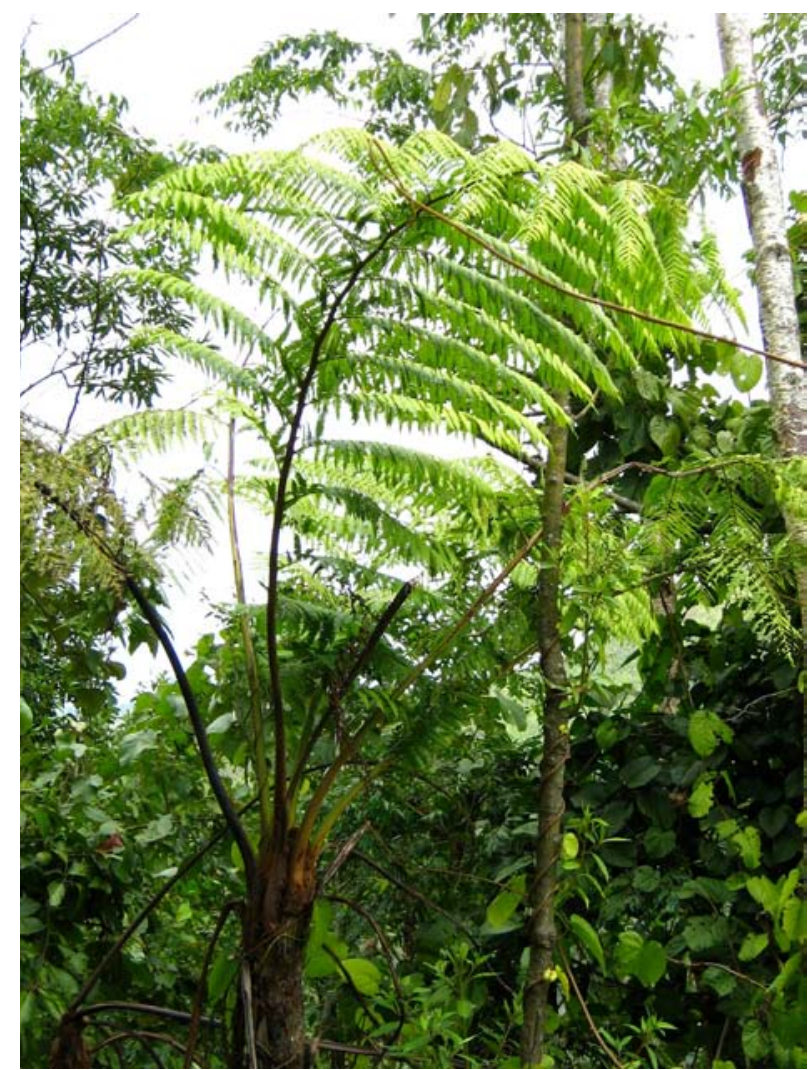

Image 11. Alsophila gigantea

Khasi and southern Garo Hills) but a new record for the Garo District. It is widely distributed in northeastern India (Arunachal Pradesh, Meghalaya, Nagaland, Sikkim), Bhutan, Myanmar and Nepal.

\section{Dennstaedtiaceae}

Dennstaedtia scabra (Wall. ex Hook.) T. Moore.: Terrestrial in moist places in slopes in semi-shaded places. Rongsingiri (600m) VNS \& BS 115892 (Assam). This species grows occasionally in Nokrek, and recorded for the first time from Garo Hill District. It is widely distributed in northern India (Kashmir, Punjab), northeastern India (Assam, Meghalaya, Arunachal Pradesh), Bhutan, Thailand, Indo-china, China, South Korea, Japan, Taiwan, Philippines, Malaya and Borneo.

Microlepia hancei Prantl.: Terrestrial in moist places in dense forests. Near Bandari falls (310 m) VNS \& BS 114977 (Assam). This species is rare in Nokrek, and recorded for the first time from Meghalaya. It is widely recorded from Taiwan, China (Guangdong, Guangxi) and Vietnam.

Microlepia platyphylla (D. Don) J. Sm.: Terrestrial

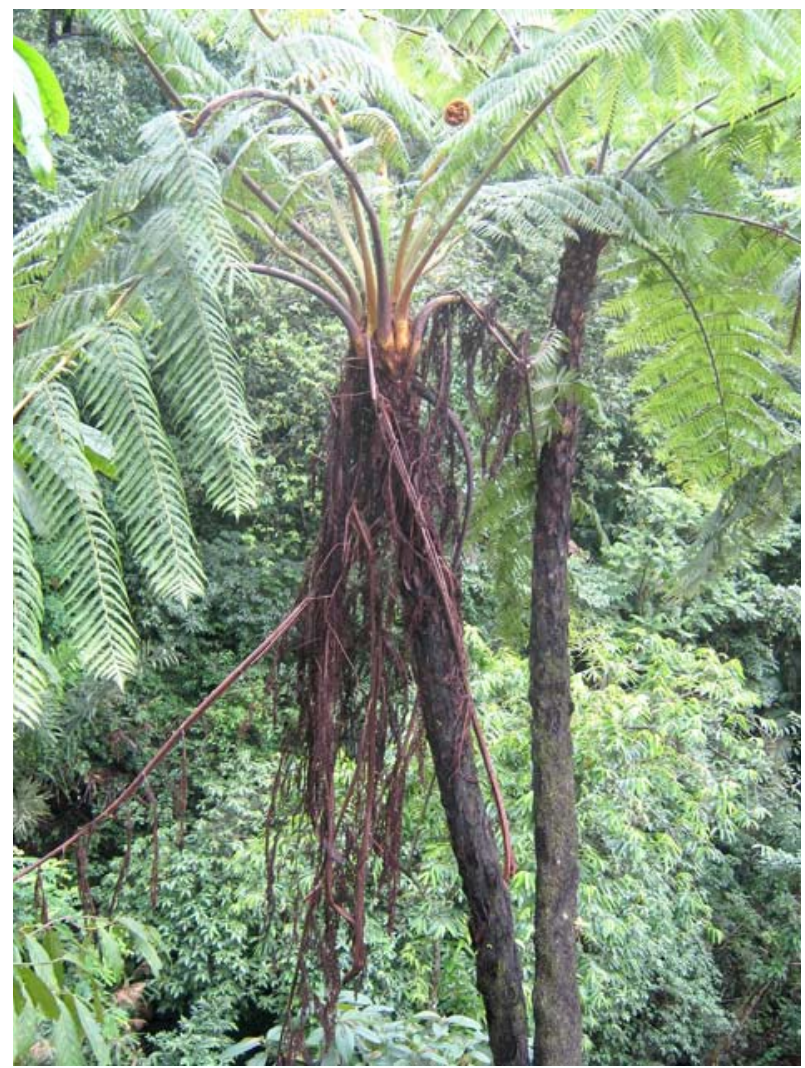

Image 12. Alsophila khasiana

in moist as well as in open places on wet ground, commonly along streams and rivers in semi-shady places. Tura ridge $(720 \mathrm{~m})$ VNS \& BS 114903 (Assam). Although this species is common in Nokrek, it is a new record for the Garo District. This species is widely distributed in Bangladesh, northeastern India, China, Thailand, Indo-china, Taiwan, and Philippines.

Microlepia rhomboidea (Wall. ex Kunze) Prantl.: Terrestrial in moist places. Nokrek Peak (1150m) VNS \& BS 116756 (Assam), Niengsanggre-Adugre (500m)

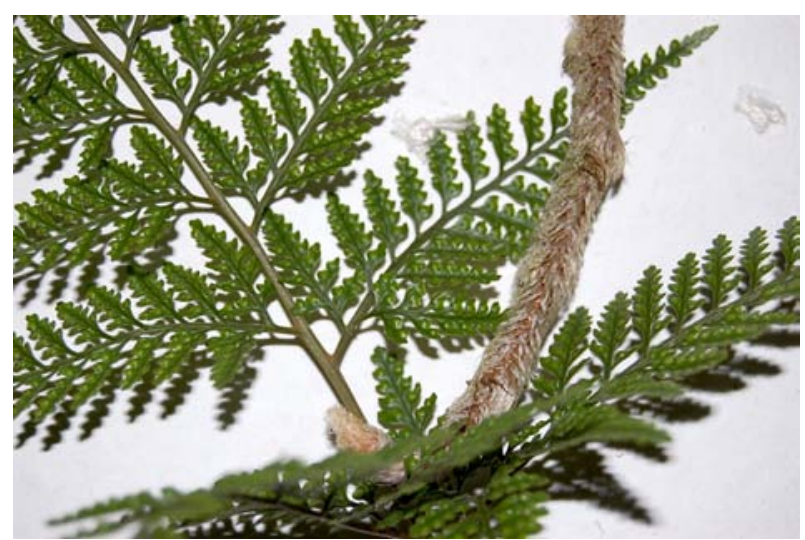

Image 13. Davallia griffithiana 
VNS \& BS 118203 (Assam). This species is rare in Nokrek, and recorded for the first time from Meghalaya. It is recorded from the Himalayan regions.

Microlepia speluncae (L.) T. Moore.: Terrestrial in moist places on slope sides in open or semi-shaded places or on edges of forests at lower elevations. Tura ridge (800m) VNS \& BS 114893 (Assam). It is common in Nokrek, and is a new record for the Garo Hill districts. This species is widely distributed in pantropical regions.

Pteridium aquilinum (L.) Kuhn.: Terrestrial in open places. Daribokgre (500-900 m), VNS \& BS 114573A (Assam). The species is very common in Nokrek and widely distributed in northeastern India (Assam, Arunachal Pradesh, Meghalaya, Manipur, Nagaland), Bangladesh, China, Sri Lanka and Taiwan.

\section{Drynariaceae}

Drynaria propinqua (Wall. ex Mett.) J. Sm. Epiphytic on moss covered tree trunks, rarely lithophytic on rock surfaces. Williamnagar to $5 \mathrm{~km}$ way to Peak (425m) VNS \& BS 115933 (Assam). This species is common in the southern slopes of Nokrek, but rare in other parts in the reserve area. It is a new record for the Garo Hill districts. It is widely distributed in northern India (Kashmir, Uttaranchal), northeastern India (Arunachal Pradesh, Meghalaya (Assam), Bhutan, China, Malaya, Malesia, Myanmar and Nepal.

Drynaria quercifolia (L.) J. Sm.: Epiphytic on tree trunks in shady places. Foot hills of Nokrek Peak (300m) VNS \& BS 114944 (Assam). This species is very common in Nokrek, and widely distributed throughout the Himalayan regions as well as northeastern India, Australia, China, Fiji, Malaya and Sri Lanka.

\section{Dryopteridaceae}

Arachniodes aristata (G. Forst.) Tindale. Terrestrial in shady places. Nokrek Peak (1230m) VNS \& BS 114706 (Assam). This species is rare in Nokrek, and recorded for the first time from Garo Hill districts. It is distributed in New Zealand (Raoul Island), Asia, Australia and the Pacific Islands.

Dryopteris cochleata (Buch.-Ham. ex D.Don) C.Chr.: Terrestrial in moist places. Tura Peak (950 m) VNS \& BS 114904 (Assam). This is extremely rare in Nokrek, and recorded for the first time from
Garo Hill districts. It is distributed in northeastern India (Arunachal Pradesh, Meghalaya), northern India (Dehradun), North America.

\section{Gleicheniaceae}

Dicranopteris lanigera (D. Don) Fraser.-Jenk.: Terrestrial in open places. Dopggre (200-600 m) VNS \& BS 114987A (Assam). This species is common in Nokrek, and distributed throughout the Himalayan region.

Dicranopteris linearis (Burm.f.) Underw.: Terrestrial in open places. Khalakgre $(750 \mathrm{~m})$ VNS \& BS s.n. (Assam). Although this species is common in Nokrek, it is recorded for the first time from Meghalaya. It is also widely distributed in Southeast Asia.

Dicranopteris splendida (Hand.-Mazz.) Tagawa.: Terrestrial in moist places. Nabokgre (850m) VNS \& BS 116818 (Assam). It is common in Nokrek and is widely distributed in northeastern India (Arunachal Pradesh, Meghalaya), Myanmar and Vietnam.

\section{Hemionitidaceae}

Coniogramme procera Wall. ex Fée. Terrestrial in moist places near rivers. Nokrek Peak (1350m) VNS \& BS 114691 (Assam). This is common in Nokrek, and recorded for the first time from Meghalaya, hence is a new record for the state. It is distributed in the Himalayan region of India.

Pityrogramma calomelanos (L.) Link. Terrestrial in open places. Khalakgre (800m) VNS \& BS 116718 (Assam). It is very common in Nokrek, widely distributed in northeastern India (Arunachal Pradesh, Assam, Meghalaya, Nagaland), Taiwan, Hainan and Yunnan.

\section{Hymenophyllaceae}

Mecodium tenellum (D. Don) Sarn. Singh \& Panigrahi: On moss covered tree trunks in moist areas. Nokrek Peak (11200m) DBD 28917 (Assam). It is extremely rare in Nokrek, and recorded for the first time from Garo Hill districts of Meghalaya; although the cited specimens are housed in Assam herbarium, no publication appeared so far from the Garo Hills. This species is widely distributed in southern India, eastern Himalayan regions of India, Bhutan, China, Nepal, Malaya, Myanmar, Sri Lanka and Thailand.

Mecodium javanicum (Spreng.) Cop: On tree trunks in moist and shady places. Nokrek Peak (1200m) 
GP 22562 (Assam). It occurs rarely in Nokrek, but is widely reported from northeastern India (Assam, Meghalaya), Australia, Myanmar, New Zealand, Philippines and Sri Lanka.

\section{Lindsaeaceae}

Lindsaea odorata Roxb. ex Griff. (Image 14): Epiphytic as well as terrestrial. Tura ridge $(750 \mathrm{~m})$ VNS \& BS 118318A. It is very common in Nokrek, and is a new record for Garo District. It is widely distributed in northeastern India (Assam, Arunachal Pradesh, Meghalaya), tropical Asia from Ceylon to New Guinea.

Sphenomeris chinensis (L.) Maxon.: Terrestrial along river sides. Tura Peak (1100m) VNS \& BS 118318 (Assam). This species is rare in Nokrek, and is a new record for the Garo Hill districts. According to Baishya \& Rao (1982), this species is common in Khasi and Jaintia districts of Meghalaya. It is mostly indigenous to Hawaii Islands, parts of Polynesia, and east Asia. It is commonly found in forest openings and other disturbed areas such as along trails or roads, or on landslides when there is adequate moisture.

\section{Lomariopsidaceae}

Bolbitis sinensis (Baker) K. Iwats.: Terrestrial in deep gullies in shady places. Along Simsang River from Daribokgre (755m) VNS \& BS 114662 (Assam). This species is rare in Nokrek, and recorded for the first time from Meghalaya and is a new record for the state. It is distributed in the eastern Himalaya.

\section{Loxogrammaceae}

Loxogramme chinensis Ching.: Epiphytic as well as lithophytic in dense forests. Nokrek Peak (902m) BS 118578A (Assam). This species is occasionally found in Nokrek, and recorded for the first time from Meghalaya. It is widely distributed in northeastern India (Assam, Arunachal Pradesh, Meghalaya), Bhutan, China, Japan, Myanmar, Thailand and Taiwan.

Loxogramme involuta (D. Don) C. Presl.: Epiphytic as well as lithophytic in dense forests in shady areas. Near Daribokgre along Simsang River (850m) VNS \& BS 116733 (Assam), on the way to Nokrek Peak from Tura Peak (1210m) MKV Rao 64378 (Assam). This species is occasionally recorded from Nokrek. It is distributed in northeastern India (Arunachal Pradesh, Meghalaya), Bhutan, China, Malesia, Nepal, Polynesia

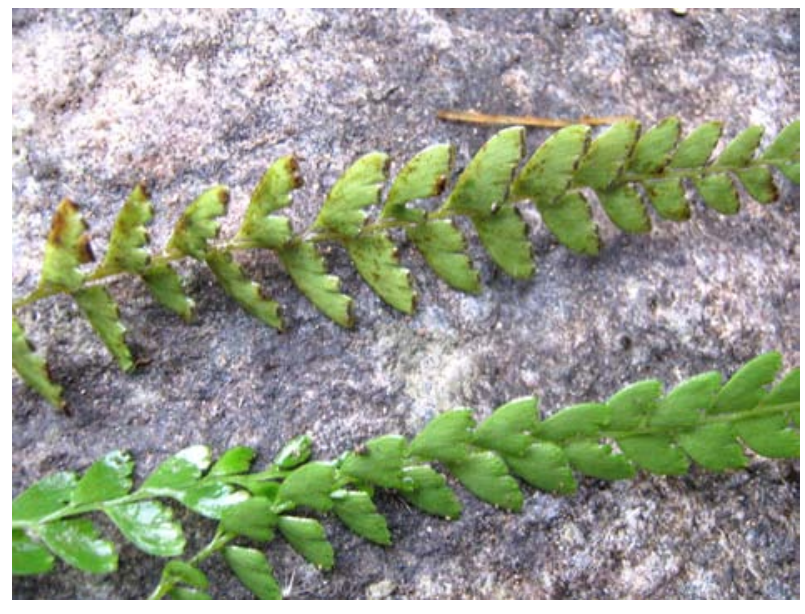

Image 14. Lindsaea odorata

and Sri Lanka.

\section{Lygodiaceae}

Lygodium flexuosum (L.) Sw. (Image 15): Climber along forest margins. Daribokgre along Simsang River (820m) VNS \& BS 114658 (Assam). On way to Durabandagre (600 m) VNS \& BS 115804 (Assam). This species is common in Nokrek and is a new record for the Garo District. It is widely distributed throughout India especially in the hilly areas of the eastern Humalayas, Africa, Australia, China, Malayasia and Sri Lanka.

Lygodium japonicum (Thunb.) Sw.: Climber in moist places. Khalakgre (800m) VNS \& BS 118287 (Assam). This species is extremely rare in Nokrek, and is a new record for the Garo Hill districts. Distributed in the western Himalaya, southern India, northeastern India (Arunachal Pradesh, Assam, Meghalaya), Australia, China, Japan, Korea, Malesia, Philippines and Sri Lanka.

Lygodium microphyllum (Cav.) R.Br.: Climber in dense forests as well as in open areas. Very rare in Nokrek, and recorded for the first time from Meghalaya. It is distributed in northeastern India (Assam, Arunachal Pradesh. Meghalaya), southern India (Kerala, Tamil Nadu), Africa, Australia, Hong Kong, Malayasia and Sri Lanka.

\section{Marattiaceae}

Angiopteris helferiana C. Presl. (Image 16): Arborescent ferns along forest margins and river sides. Along Simsang river from Daribokgre (780m) VNS \& BS 114657 (Assam), Tura Peak (880m) VNS 


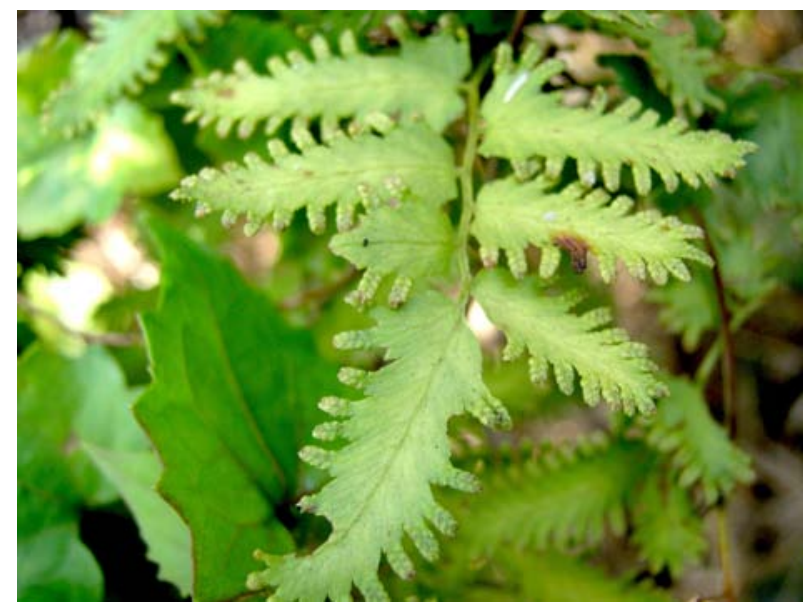

Image 15. Lygodium flexuosum

\& BS 114894 (Assam). Rare in Nokrek, and widely reported from northeastern India, Australia, China, Japan, Madagascar, Malaysia, New Caledonia and Polynesia. It is known by the name of Angiopteris evecta, but according to Fraser-Jenkins (2008), there is no such species in India and neighbouring countries. The species which is found in the Indian subcontinent is Angiopteris helferiana.

\section{Nephrolepidaceae}

Nephrolepis cordifolia (L.) C. Presl.: Terrestrial in dense forests as well as in damp places on rocks. Common in Nokrek, and widely distributed throughout hilly areas of India.

\section{Polypodiaceae}

Aglaomorpha coronans (Wall. ex Mett.) Cop.: On huge tree trunks in dense forests. Sisubibra (450m) BS \& VNS 116711 (Assam). Very common in Nokrek, and widely distributed in northeastern India, Bangaldesh, Bhutan, China, Hong Kong, Malaya, Nepal and Taiwan.

Arthromeris lehmanni (Meth.) Ching.: On big tree trunks in dense forests. Nokrek Peak (1270m) BS 118577A (Assam). Rare in Nokrek, and is a rew record for the Garo District. According to Baishya \& Rao (1982), this species is very rare in Meghalaya. Distributed in northeastern India, China, Myanmar, Thailand, Taiwan and Vietnam.

Arthromeris wallichiana (Spreng) Ching.: Epiphyte on tree trunks of Quercus (Tourn.) L. and Castanopsis Spach in dense forests. Nokrek Hills (700m) GP 3973 (Assam). Rare in Nokrek, and is a new record for the

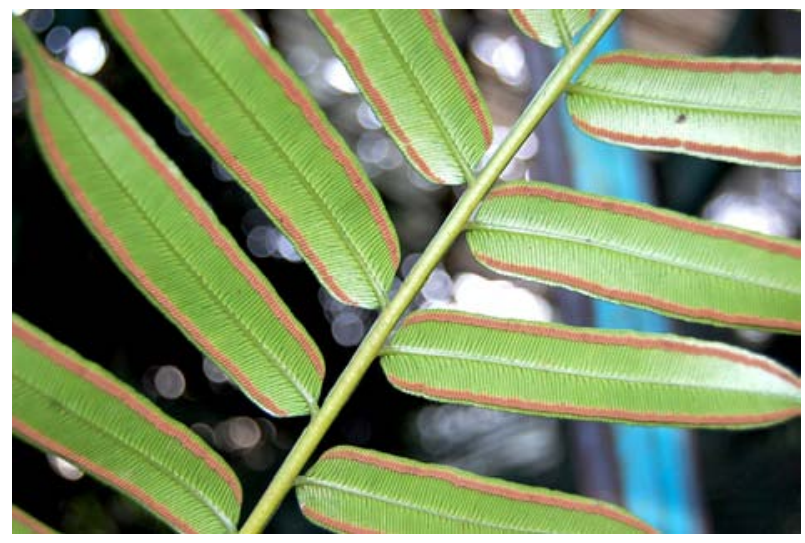

Image 16. Angiopteris helferiana

Garo districts, although the cited specimens are housed in Assam herbarium. This species is distributed in India (Meghalaya, Sikkim, Nagaland), Burma and China.

Belvisia callifolia (D.N. Christ) Cop.: Epiphyte on moss covered tree trunks in dense forests. Nokrek Peak (1300m), BS 118477A (Assam). Rare in Nokrek, also very rare in Meghalaya (Baishya \& Rao 1982). It is widely distributed in northeastern India (Arunachal Pradesh, Meghalaya), Nepal.

Belvisia henryi (Hieron. ex C.Chr.) Raymond.: Epiphytic as well as lithophytic in forest understory. On way to Adugre (870m) BS \& Party 114763A (Assam). It is rare in Nokrek, and a new record for the Garo District. It is distributed in northeastern India, but rare in Meghalaya (Baishya \& Rao 1982). Widely occurs in China, Thailand and Vietnam.

Belvisia mucronata (Fée) Cop.: Epiphytic on tree trunks of Citrus indica Tanaka and Artocarpus heterophylla Lam. in moist and shady places. Way to Nokrek Peak (972m) BS 118562 (Assam). This species is rare in Nokrek, also reported very rare in Meghalaya (Baishya \& Rao 1982). Widely distributed in India (Assam, Arunachal Pradesh, Meghalaya, Sikkim, Western Ghats), Bhutan, China, Malaysia, Philippines, Polynesia, Sri Lanka and Taiwan.

Colysis decurrens (Blume) Panigrahi.: Epiphytic as well as lithophytic along rivers and stream sides in dense forests. Nokrek Peak (850m) BS \& Party 118502 (Assam). Occasional in Nokrek, but widely distributed in northeastern India, China, Malaya, Myanmar, Nepal, Taiwan and Vietnam.

Colysis hemionitidea (Wall. ex Mett.) C. Presl.: Epiphytic as well as lithophytic along rivers and stream 
sides in dense forests. Tura top Hills (860m) GP 22481 (Assam). It is rare in Nokrek. This species was also reported from Tura Peak at an elevation of $700 \mathrm{~m}$ by Baishya \& Rao (1982); widely distributed in southern India, northeastern India, Bangladesh, Bhutan, China, Malaya Islands, Japan, Myanmar, Nepal, Taiwan and Vietnam.

Colysis pedunculata (Hook. \& Grev.) Ching.: Epiphytic on moss covered tree trunks, sometimes found at the base of tree trunks. Tura Peak $(1190 \mathrm{~m})$ GP 22384 (Assam). Rarely occurs in Nokrek, and also reported by Baishya \& Rao (1982) to be very rare in Meghalaya. Widely distributed in northeastern India, Bangladesh, Bhutan, China, Malaya, Myanmar and Nepal.

Drymoglossum heterophyllum (L.) Trimen.: Epiphytic on exposed tree trunks. Patalgiri $(570 \mathrm{~m})$ VNS \& BS 116880A (Assam). Very common in Nokrek, but widely distributed in southern India (Kerala, Tamil Nadu), northeastern India (Assam, Arunachal Pradesh, Meghalaya), central India, China, Japan, Java, New Guinea, Myanmar, Philippines and Sumatra.

Lemmaphyllum carnosum (Wall.) C. Presl.: Creeping on tree trunks laden with moss in moist places. Nabokgre to Patalgiri (500-1200 m) VNS \& BS 116869 (Assam), Tura top (900m) GP 22482 (Assam). Occasional in Nokrek, and recorded for the first time from Garo Hill districts. Widely distributed in northeastern India (Arunachal Pradesh, Meghalaya), northern India, China, Nepal and Thailand.

Lemmaphyllum microphyllum C. Presl.: Epiphytic on moss ladden tree trunks. Patalgiri to Simsangiri (700-1000 m) VNS \& BS 116880B (Assam). Recorded for the first time from Meghalaya (east Garo Hills), hence is a new record for Meghalaya. Occasional in Nokrek, and widely distributed in northeastern India (Arunachal Pradesh, Meghalaya, Assam), China, Hong Kong, Japan, Korea, Taiwan and Vietnam.

Lemmaphyllum rostratum (Bedd.) Tagawa.: Epiphytic on tree trunks in dense forests. Tura Peak (1320m) VNS \& BS 114901 (Assam). Recorded for the first time from the state. Very rare in Nokrek, distributed in northeastern India (Arunachal Pradesh, Meghalaya (east Garo Hills), Nagaland), China, Myanmar, Taiwan and Vietnam.

Leptochilus axillaris (Cav.) Kaulf.: Epiphytic, creeping on tree trunks. Near Didari River (850m) BS
\& VNS 114563 (Assam). Very rare in Nokrek, and is a new record for the Garo Hill districts of Meghalaya. According to Baishya \& Rao (1982), this species is very rare in Meghalaya. It is recorded from southern India (Kerala), northeastern India (Assam, Meghalaya, Arunachal Pradesh), Bangladesh, China, Malaya, Myanmar, Philippines, Polynesia and Thailand.

Microsorium insigne (Blume) Cop.: Epiphytic on tree trunks along river/stream sides. Nokrek core area (1150m) BS \& Party s.n. (Assam). It was treated in India for a long time under the name Microsorum dilatatum (Bedd.) Sledge. The species is rare in Nokrek, and widely distributed in northeastern India (Assam, Meghalaya, Arunachal Pradesh), China, Malacca, Malaya, Myanmar and Sri Lanka.

Microsorum membranaceum (Don) Ching.: Epiphytic on tree trunks along rivers and stream sides. On way to Tura Peak (750m) MKVR 63957 (Assam), Tura Peak (900m) DBD 28961 (Assam), Tura top hill (1100m) GP 22483 (Assam). Common in Nokrek, widely recorded from northeastern India (Assam, Arunachal Pradesh, Meghalaya), China, Myanmar and Sri Lanka.

Microsorum pteropus (Blume) Cop.: Epiphytic as well as lithophytic in moist places along river and stream sides. Rare in Nokrek (Garo Hills), reported by Baishya \& Rao (1982) from the study site. Widely distributed in southern India, northeastern India (Nagaland, Meghalaya, Sikkim), Bangladesh, Bhutan, Malaysia, Myanmar, Nepal and Sri Lanka.

Microsorum punctatum (L.) Cop. (Image 17): Epiphytic on decaying tree trunks in shady places. Tura hills (850m) GP 22508 (Assam). Found occasionally in Nokrek, and widely distributed in India, Africa, Polynesia, China and Taiwan.

Microsorum zippelii (Blume) Ching.: Epiphytic on decaying tree trunks in shady places and cliffs along stream sides. Nokrek Peak (1350m) BS \& Party 118502 (Assam). Rare in Nokrek, widely distributed in northeastern India, China, Malaya, Malesia, Philippines and Vietnam.

Phymatosorus cuspidatus (D. Don) Pic.-Serm. (Image 18): Epiphytic on humic tree trunks in shady places along river sides. On way to Patalgre (460m) BS \& VNS 116836 (Assam). Recorded by Baishya \& Rao (1982) from Rongrengiri area at an elevation of about $150 \mathrm{~m}$. Rare in Nokrek, also reported rare in Meghalaya by (Baishya \& Rao (1982). Widely 


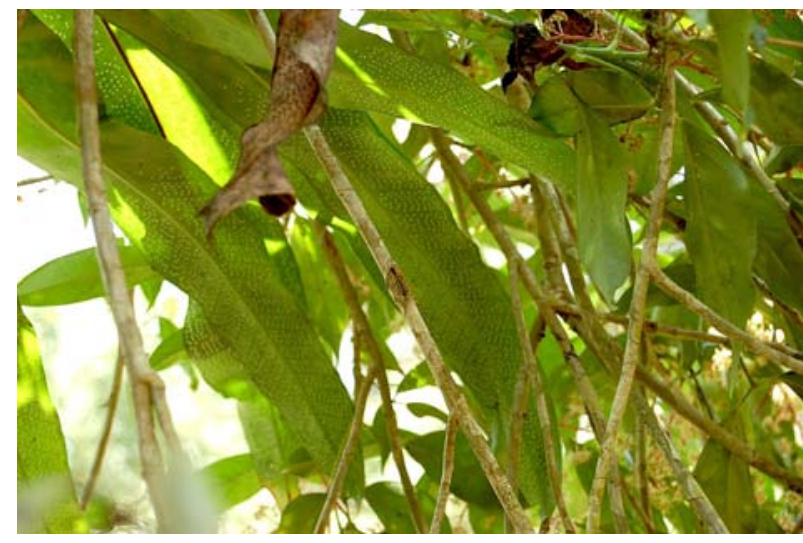

Image 17. Microsorum punctatum

distributed in northeastern India (Arunachal Pradesh, Assam, Meghalaya, Nagaland), southern India (Western Ghats), China, Laos, Nepal and Vietnam.

Pleopeltis contorta (Christ) Alston \& Bonner.: Epiphytic on tree trunks in damp places. Patalgiri to Simsanggiri (350-900 m) VNS \& BS 116878 (Assam), Simsanggiri to $15 \mathrm{~km}$ inside buffer zone $(700 \mathrm{~m})$ VNS \& BS 116792. Occasionally in Nokrek, and recorded for the first time from Garo District. It is reported from northeastern India (Arunachal Pradesh, Meghalaya, Nagaland, Sikkim), China and Tibet.

Pleopeltis macrosphaera (Baker) Panigrahi \& Patnaik.: Epiphytic on tree trunks in dense forests. Nokrek Peak (850-1200 m) VNS \& BS 114726 (Assam), Tura Peak (720m), MKVR 64381 (Assam). Rare in Nokrek, and recorded for the first time from Meghalaya. It is distributed in northeastern India (Arunachal Pradesh, Meghalaya), China.

Pleopeltis nuda Hook.: Epiphytic on moss tree trunks in damp places. Daribokgre to East Down Hills (862m) VNS \& BS 114598 (Assam), Tura Peak (960m) DBD 28956 (Assam). Common in Nokrek, and recollected after 50 years from Garo districts. Distributed in northeastern India, Africa, China, Japan, Malaya and Sri Lanka.

Pyrrosia adnascens (Sw.) Ching. (Image 19): Epiphytic on tree trunks in open as well as dense forests. Daribokgre along Didari Chibima River (960m) VNS \& BS 114562 (Assam), Tura Peak (750m) DBDeb 28843 (Assam). Common in Nokrek, widely distributed throughout northeastern India, China, Fiji, Malaya, Philippines, Polynesia, Sri Lanka, Taiwan and Vietnam.

Pyrrosia costata (Presl) Tagawa \& K. Iwats.:

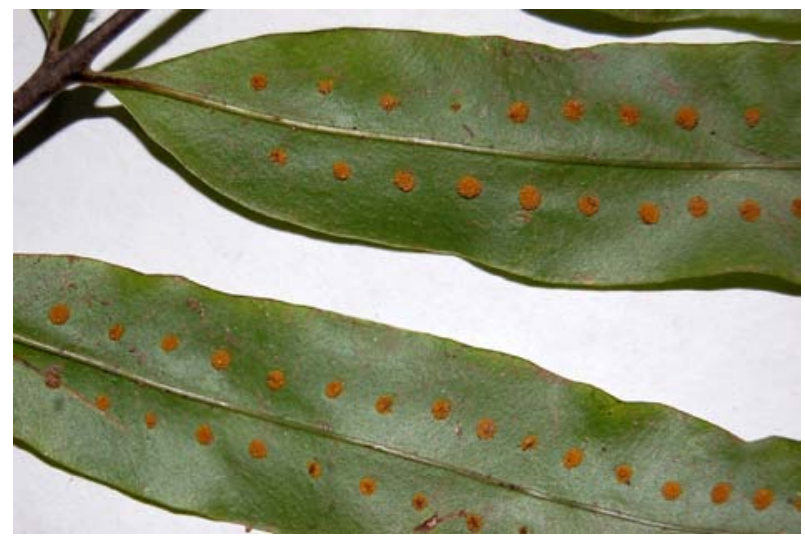

Image 18. Phymatosorus cuspidatus

Epiphytic on tree trunks along river sides. Tura Peak (950m) GP 224741 (Assam), on way to Tura Peak (600m) MKVR 64339 (Assam). Recorded from northeastern India (Assam, Arunachal Pradesh, Meghalaya), China, Myanmar and Thailand.

Pyrrosia flocculosa (D. Don) Ching. (Image 20): Epiphytic as well as lithophytic in moist places. Nokrek Peak (1120m) VNS \& BS 115997 (Assam), Tura Peak (800m) MKVR 59094 (Assam), Tura Peak (900m) DBD 28959 (Assam). Common in Nokrek (Garo Hills), and widely distributed in northeastern India (Assam, Meghalaya, Nagaland), Bhutan, China, Myanmar, Nepal and Vietnam.

Pyrrosia heteractis (Mett. ex Kuhn) Ching.: Epiphytic in moist places. Rongrengiri (295m) VNS \& BS 114562A (Assam), MKVR 64339 (Assam), Tura Peak (670m) MKVR 59094 (Assam). Occasionally in Nokrek, and recorded for the first time from Garo Hill districts of Meghalaya. This species is distributed in northeastern India (Assam, Arunachal Pradesh, Meghalaya, Nagaland, Sikkim), Bhutan, China, Myanmar and Sri Lanka.

Pyrrosia lanceolata (L.) Farw.: Epiphytic in dense forests. Rongrengiri (295m) VNS \& BS 116762b (Assam). Rare in Nokrek, and is a new record for Meghalaya. This species is very similar to Pyrrosia adnascens, but differs in certain characters. Widely distributed in southern India, northeastern India (Arunachal Pradesh, Meghalaya, Sikkim), Bhutan, China, Japan, Polynesia, Sri Lanka and Taiwan.

Pyrrosia longifolia (N.Burm.) F. Morton.: Epiphytic on tree trunks along roadsides. Daribokgre along Didari Chibima River (960m) VNS \& BS 114559 (ASSAM), Nokrek Peak (1200m) BS \& VNS 


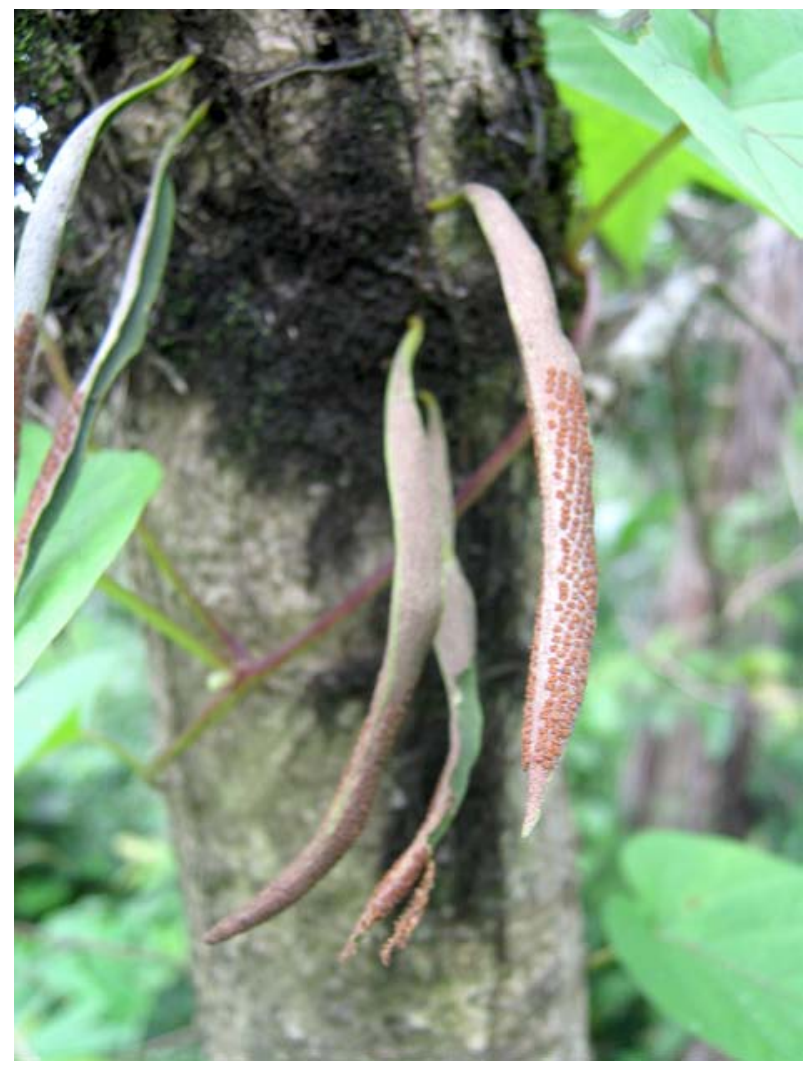

Image 19. Pyrrosia adnascens

s.n. (ASSAM 74702). Rare in Nokrek, and recorded for the first time in Meghalaya. Widely distributed in northeastern India (Arunachal Pradesh, Meghalaya), Australia, Malaya, Malaysia and Polynesia.

Pyrrosia nuda (Gies.) Ching.: Epiphytic on barky tree trunks. Rongrengiri (295m) VNS \& BS 116762A (ASSAM). Rare in Nokrek, and recorded for the first time from Garo District. Widely reported from Himalayan regions of India, Nepal and China.

Pyrrosia nummularifolia (Sw.) Ching.: Epiphytic as well as lithophytic along river sides. Ningsangiri (650m) VNS \& BS 118209 (Assam), along Simsang river from Daribokgre, VNS \& BS 114660 (Assam). Common in Nokrek, but a new record for the Garo District. Widely distributed throughout northeastern India, Bhutan, Bangladesh, China, Malaya, Malaysia, Philippines and Vietnam.

\section{Pteridaceae}

Pteris biaurita L. subsp. fornicata Fraser.-Jenk.: Terrestrial in moist places. Tura Peak (680m) VNS \& BS 114896 (Assam). Occasionally in Nokrek, and is a new record for the Garo Hill districts of Meghalaya.

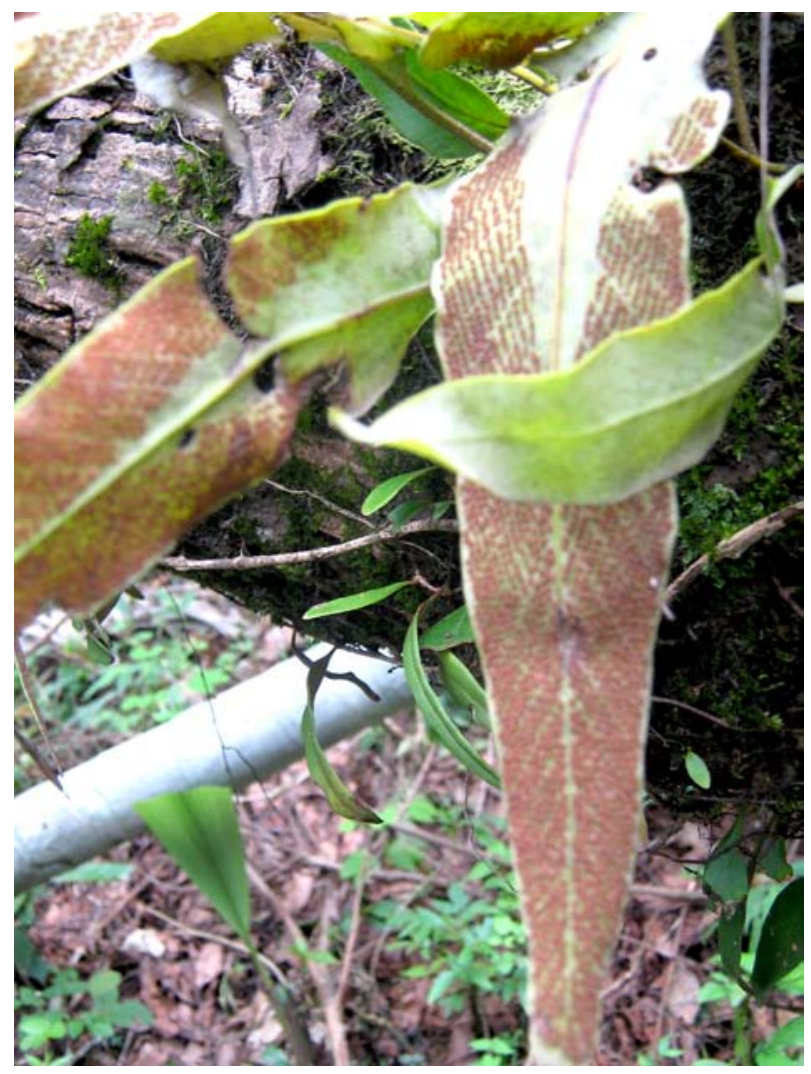

Image 20. Pyrrosia flocculosa

Although it is recorded from the Khasi and Jaintia Hill districts, it has not been identified up to subspecies level.

Pteris biaurita L. subsp. walkeriana Fraser.-Jenk. \& Dominic Rajkumar: Terrestrial along river sides. Nabokgre to Patalgre (600-820 m) VNS \& BS 116867 (Assam), Simsanggiri to $15 \mathrm{~km}$ inside core zone (900m) VNS \& BS 116800 (Assam). Very rare in Nokrek, and recorded for the first time in Meghalaya.

Pteris ensiformis Burm. f.: Terrestrial in open as well as in moist places. Rongrenggiri (350m) VNS \& BS 116774 (Assam). Although very common in Nokrek, and is a new record for the Garo District. Distributed in northeastern India, Nepal.

Pteris grevilleana Wall. ex T.Agardh.: Terrestrial as well as lithophytic in wet places. Rongrenggiri (350m) VNS \& BS 116867 (Assam). Very rare in Nokrek, and recorded from east Garo Hills and is a new record for the state.

Pteris longipes D. Don.: Terrestrial in moist places. Nokrek Peak (1230m) VNS \& BS 114690 (Assam). Growing occasionally in Nokrek, and according to Baishya \& Rao (1982) is widely distributed in Garo 
districts. Distributed in southern India, northeastern India, China and Sri Lanka.

Pteris longipinnula Wall.ex J.Agardh.: Terrestrial in wet places. Rongsingre (500m) VNS \& BS 115891 (Assam). Extremely rare in Nokrek, and a new record for the Garo District.

Pteris vittata L.: Terrestrial along river sides. Niengmandalgre (600m) VNS \& BS 116843 (Assam). Very common in Nokrek, and widely distributed throughout Himalaya including northeastern India, southern India, central India, China and Sri Lanka.

\section{Tectariaceae}

Tectaria fuscipes (Wall. ex Bedd.) C. Chr.: Terrestrial in moist places. Foot hills of Nokrek range (300-700 m) VNS \& BS 116843 (Assam), Rongrengre (150m) VNS \& BS 118238 (Assam). Although very common in Nokrek, is a new record for the state. Widely distributed in eastern Himalaya, northeastern India (Nagaland, Meghalaya), Myanmar.

Tectaria polymorpha (Wall. ex Hook.) Cop.: Terrestrial along road sides. On way to Khalakgre (750m) VNS \& BS 115989 (Assam). Common in Nokrek, but is a new record for the Garo District. Distributed in southern India, northeastern India, eastern Himalaya, Bangladesh, Indonesia, Malaysia, Myanmar, Philippines and Sri Lanka.

\section{Thelypteridaceae}

Cyclosorus crinipes (Hook.) Ching.: Terrestrial in moist places. Tura ridge (980m) VNS \& BS 118312 (Assam). Rare in Nokrek, and widely distributed in the eastern Himalayan region. This is a new record for Meghalaya.

Cyclosorus dentatus (Forsk.) Ching.: Terrestrial in wet places near the river. Nokrek Peak $(1230 \mathrm{~m})$ VNS \& BS 116721A (Assam). Rare in Nokrek, and recorded for the first time from Garo Hill districts. Widely distributed in northeastern India, Taiwan, Fujian, Jiangxi, Guangdong, Guangxi, Yunnan, Guizhou. Vietnam, Thailand, Myanmar and Tropical America.

Pseudocyclosorus falcilobus (Hook.) Ching.: Terrestrial in wet places. Bansamgre (308m) VNS \& BS 118255 (Assam). Rare in Nokrek, and recorded for the first time and in Meghalaya. Widely distributed in northeastern India, eastern and southern China, Japan, Indochina.
Pronephrium lakhimpurense (Ros.) Holtt.: Terrestrial along forest margins. Tura ridge (970m) VNS \& BS 114895 (Assam). Very rare in Nokrek, and recorded for the first time from Garo District. Widely distributed in northeastern India (Assam, Arunachal Pradesh, Meghalaya), Sichuan, Yunnan and Thailand.

Pronephrium nudatum (Roxb. ex Griff.) Holtt.: Terrestrial along river sides. Ronsingiri $(450 \mathrm{~m})$ VNS \& BS 115861 (Assam). Rare in Nokrek, and is widely distributed in northeastern India (Assam, Arunachal Pradesh, Meghalaya), northern India (Uttranchal), Bangladesh.

Thelypteris clarkei (Bedd.) C.F. Reed.: Terrestrial in moist places. Chokpot (312m) VNS \& BS 115712 (Assam). Extremely rare in Nokrek, but widely distributed throughout the Himalayan regions including northeastern India (Arunachal Pradesh, Meghalaya), Nepal and China.

Thelypteris procera (D.Don)Fras.-Jenk.: Terrestrial along river sides. Beyond Susibibra (602m) VNS \& BS 116715 (Assam). Occasionally found growing in Nokrek, and recollected after more than 50 years from the Garo Hill districts. It is distributed in the Indian subcontinent and other parts of tropical Asia.

Trigonospora ciliata (Wall. ex Benth.) Holtt.: Terrestrial in dense forests. Ningsangre (720m) VNS \& BS 118202 (Assam). Extremely rare in Nokrek, and reported for the first time. Distributed in Sri Lanka, Nepal and northeastern India (Arunachal Pradesh, Meghalaya).

\section{Vittariaceae}

Antrophyum obovatum Baker.: Epiphytic in dense forests. Nokrek Peak (1300m) BS 114700A (Assam). Extremely rare in Nokrek, and recorded only from the above locality. According to Baishya \& Rao (1982), the species is recorded only from Khasi Hills of Meghalaya. Widely distributed in India (Arunachal Pradesh, Darjeeling, Meghalaya, Sikkim), China and Nepal.

Antrophyum plantagineum (Cav.) Kaulf.: Epiphytic in dense forests. On way to Nokrek Peak (1000m) BS 118600 (Assam). Rare in Nokrek. Baishya \& Rao (1982) reported from southern Garo Hill (Baghmara). It is distributed in northeastern India (Assam, Arunachal Pradesh, Meghalaya), southern India (Tamil Nadu), Sri Lanka, Nepal, Polynesia and Australia.

Antrophyum reticulatum (G. Forst.) Kaulf.: 
Epiphytic in dense forests along river sides. On way to Jetagiri (470m) BS 118594 (Assam), Tura Peak (960m) DBD 28957 (Assam), Way to Baghmara (350m) GP 22531 (Assam). Rare in Nokrek, but fairly common in Meghalaya. Distributed in India (Assam, Meghalaya, Sikkim, Tamil Nadu), Nepal.

Vittaria elongata Sw.: Epiphytic on moss covered tree trunks in shady places. Darugiri RF (350m) MKVR 64154 (Assam), on way to Baghmara (400$500 \mathrm{~m}$ ) MKVR 64471 (Assam). Occasional in Nokrek, reported from northeastern India (Arunachal Pradesh, Meghalaya and Sikkim), Africa, Australia, Bangladesh, China, Loas, Malayesia, Philippines, Polynesia, Sri Lanka and Vietnam.

\section{Woodsiaceae (Athyriaceae)}

Athyrium drepanopterum (Kunze) A.Br. ex Milde.: Terrestrial along riverine areas. Chandigre (300-500 m) VNS \& BS 114743 (Assam). Rare in Nokrek, and recorded for the first time from Garo district. Distributed in China, northeastern India (Arunachal Pradesh, Meghalaya), Nepal.

Diplazium apicisorum Panigrahi \& S. Singh.: Terrestrial in moist places. Nokrek Peak (452m) VNS \& BS 114681 (ASSAM). It is very rare in Nokrek, and recorded for the first time from Meghalaya. Widely recorded in the eastern Himalaya regions.

Diplazium pseudosetigerum (H. Christ) FraserJenk.: Terrestrial along forest margins. Nokrek Peak (1100-1300 m) VNS \& BS 114681 (Assam). It is a new record for Meghalaya. Widely recorded from only northeastern India especially in the Himalayan region.

\section{CONCLUSION}

A total of 113 taxa were found in the Nokrek Biosphere Reserve of Meghalaya, evidencing the pteridophyte richness of the area. They include 25 new distribution records for Meghalaya (Selaginella involvens, Selaginella semicordata, Selaginella subdiaphana, Selaginella tenuifolia, Asplenium gueinzianum, Asplenium perakanse, Microlepia hancei, Microlepia rhomboidea, Dicranopteris linearis, Coniogramme procera, Bolbitis sinensis, Loxogramme chinensis, Lygodium microphyllum, Lemmaphyllum microphyllum, Lemmaphyllum rostratum, Pleopeltis macrosphaera, Pyrrosia lanceolata, Pyrrosia longifolia, Pteris biaurita ssp. walkeriana, Pteris grevilleana, Tectaria fuscipes, Cyclosorus crinipes, Pseudocyclosorus falcilobus, Diplazium apicisorum and Diplazium pseudosetigerum) and another 43 species (Equisetum diffusum, Selaginella decipiens, Selaginella hookeri, Selaginella monospora, Asplenium cheilosorum, Asplenium ensiforme, Asplenium finlaysonianum, Asplenium nidus, Asplenium normale, Asplenium phyllitidis, Blechnum orientale, Alsophila gigantean, Alsophila khasyana, Alsophila spinulosa, Davallia griffithiana, Davallia trichomanoides, Dennstaedtia scabra, Microlepia platyphylla, Microlepia speluncae, Drynaria propinqua, Arachniodes aristata, Dryopteris cochleata, Mecodium tenellum, Lindsaea odorata, Sphenomeris chinensis, Lygodium flexuosum, Lygodium japonicum, Arthromeris lehmanni, Arthromeris wallichiana, Belvisia henryi, Lemmaphyllum carnosum, Leptochilus axillaris, Pleopeltis contorta, Pyrrosia heteractis, Pyrrosia nummularifolia, Pteris biaurita ssp. fornicata, Pteris ensiformis, Pteris longipinnula, Tectaria polymorpha, Cyclosorus dentatus, Pronephrium lakhimpurense, Trigonospora ciliata and Athyrium drepanopterum) are new records for all the three Garo Hills districts of Meghalaya. Polypodiaceae stands the dominant family of the area with 31 species followed by Aspleniaceae and Selaginellaceae with 10 species each. Asplenium is the largest genus with a maximum number of nine species, which is followed by Pyrrosia with eight species and Pteris with seven species including two subspecies. The identity of some collection requires further studies.

\section{REFERENCES}

Alston, A.H.G. (1945). An enumeration of the Indian species of Selaginella. Proceedings of the National Institute of Science of India 11(3): 211-235.

Baishya, A.K. \& R.R. Rao (1982). Ferns and Fern-allies of Meghalaya State, India. Scientific Publishers, Jodhpur, India, 162pp.

Beddome, R.H. (1883). Handbook to the Ferns of the British India, Ceylone and the Malaya Peninsula. Thacker Spink \& Co., Calcutta, India, 552pp.

Bir, S.S. (1987). Pteridophytic Flora of India: rare and endangered elements and their conservation. Indian Fern Journal 4: 95-101. 
Brummitt, R.K. \& C.E. Powell (1992). Authors of Plant Names. Royal Botanic Gardens, Kew, 736pp.

Chauhan, A.S. (1983). Dwindling taxa of Meghalaya in an assessment of threatened plants of India, pp. 142-145. In: Jain, S.K. \& R.R. Rao (eds.). An Assessment of Threatened Plants of India. Botanical Survey of India, Howrah.

Chandra, S. (2000). The Ferns of India (Enumeration, Synonyms \& Distribution). International Book Distributors, Dehra Dun, India, 459pp.

Chandra, S., C.R. Fraser-Jenkins, A. Kumari \& A. Srivastava (2008). A summary of the status of threatened pteridophytes of India. Taiwania 53(2): 170-209.

Chowdhury, H.J. \& S.K. Murti (2000). Plant Diversity and Conservation in India - An Overview. Bishen Singh and Mahendra Pal Singh, Dehradun, India, 303pp.

Clarke, C.B. \& J.G. Baker (1888). Supplementary Note on the Ferns of Northern India. Journal of the Linnean Society of London 24: 408-418.

Das, S. \& N.C. Deori (1983). A census of endemic orchids of North-East India, pp. 104-109. In: Jain, S. \& R.R. Rao (eds.). An Assessment of Threatened Plants of India. Botanical Survey of India, Howrah, India.

Datta, A. (1983). Occurrence and distribution of some rare ferns, pp. 323-327. In: Jain, S.K. (ed.). An Assessment of Threatened Plants of India. Botanical Survey of India, Howrah, India.

Dixit, R.D. (1983). Rare and interesting Pteridophytes of India, pp. 328-334. In: Jain, S.K. (ed.). An Assessment of Threatened Plants of India. Botanical Survey of India, Howrah, India.

Dixit, R.D. (1984). A Census of the Indian Pteridophytes. Flora of India-Series 4. Botanical Survey of India, Howrah, India, $177 \mathrm{pp}$.

Dixit, R.D. (1987). Lycopodiaceae of India. Bishen Singh Mahendra Pal Singh, Dehra Dun, India, 124pp.

Dixit, R.D. (1992). Selaginellaceae of India. Bishen Singh Mahendra Pal Singh, Dehra Dun, India, 196pp.

Dixit, R.D. \& N.P. Balakrishnan (1989). Additions to the endemic Pteridophytes of India and their survey-cumconservation strategies, pp. 7-13. In: Trivedi, M.L., S.S. Saini \& B.S. Gill (eds.). Plant Science Research in India. Today and Tomorrow Printers and Publishers, New Delhi, India.

Dixit, R.D. \& B.K. Sinha (2001). Pteridophytes of Andaman and Nicobar Islands. Bishen Singh Mahendra Pal Singh, Dehra Dun, India, 155pp.

Fraser-Jenkins, C.R. (1980). Nomenclatural notes on Dryopteris - 4. Taxon 29(5\&6): 607-612.

Fraser-Jenkins, C.R. (1984). An introduction to fern genera of the Indian subcontinent. Bulletin of British Museum (Natarural History) Botany Series 12(2): 37-76.

Fraser-Jenkins, C.R. (1989). A monograph of the genus Dryopteris (Pteridophyta: Dryopteridaceae) in the Indian subcontinent. Bulletin of British Museum (Natarural History) Botany Series 18(5): 323-477.

Fraser-Jenkins, C.R. (1997). Himalayan Ferns (A Guide to
Polystichum): 1-54, with errata 10.1.1998. International Book Distributors, Dehra Dun, India, 73pp.

Fraser-Jenkins, C.R. (1997). New Species Syndrome in Indian Pteridology and the Ferns of Nepal. International Book Distributors, Dehra Dun, India, 404pp.

Fraser-Jenkins, C.R. (2008). Taxonomic Revision of three hundred Indian subcontinental Pteridophytes with a Revised Census-List-a new picture of fern-taxonomy and nomenclature in the Indian subcontinent: 1-c.595. Bishen Singh Mahendra Pal Singh, Dehra Dun, India.

Fraser-Jenkins, C.R. (2008). Endemics and Pseudoendemics in Relation to the Distribution Patterns of Indian Pteridophytes. Taiwania 53(3): 264-292.

Ghosh, S.R., B. Ghosh, A. Biswas \& R.K. Ghosh (2004). The Pteridophytic Flora of Eastern India 1. Flora of India series 4. Botanical Survey of India, Kolkata, India, 591pp.

Haridasan, K. \& R.R. Rao (1984). Flora, Vegetation and plant resources of Garo Hills, pp. 97-105. In: Gassah, L.S. (ed.). Garo Hills and People. Omsons publications, Gauhati, New Delhi, India.

Haridasan, K. \& R.R. Rao (1985-1987). Forest Flora of Meghalaya-2 Volumes. Bishen Singh Mahendrapal Singh. Dehradun, India, 937pp.

IUCN (1987). Centre of Plant diversity: A Guide and Strategy for Their Conservation. IUCN Publication, UK, 167pp.

IUCN (1966). International Union for the Conservation of Nature Red Data Book. Morges, Switzerland, 213pp.

Holttum, R.E. (1971). Studies in the family Thelypteridaceae 3. A new system of genera in the Old World. Blumea 19: $17-52$.

Jagtap, A.P. \& N.P. Singh (1999). Fascicles of Flora India, pp. 1-284. In: Fascicle 24 - Asclepidiaceae. Botanical Survey of India, Calcutta, India.

Kataki, S.K. (1986). Orchids of Meghalaya. Government of Meghalaya, Shillong, India, 258pp.

Kachroo, P. (1953). Ferns of Assam. Journal of the Asiatic Society of Bengal 19: 161-174.

Kachroo, P. (1976). Fern Flora of Assam with some Phytogeographical notes. Journal of the Indian Botanical Society 54: 13-26.

Manickam, V.S. (1995). Rare and endangered ferns of the Western Ghats of South India. Fern Gazette 15: 1-10.

Nayar, M.P. (1980). Endemism and patterns of distribution of endemic genera (angiosperms). Journal of Economic and Taxonomic Botany 1: 99-110.

Nayar, M.P. (1996). Hotspots of Endemic Plants of India, Nepal and Bhutan. Thiruvanathapuram, Kerala, 320pp.

Olson, D.M., E. Dinerstein, E.D. Wikramanayake, N.D. Burgess, G.V.N. Powell, E.C. Underwood, J.A. D'amico, I. Itoua, H.E. Strand, J.C. Morrison, C.J. Loucks, T. F. Ilnutt, T.H. Ricketts, Y. Kura, J.F. Lamoreux, W.W. Wettengel, P. Hedao \& K.R. Kassem (2001). Terrestrial ecoregions of the world: a new map of life on earth. BioScience 51: 933-938.

Panigrahi, G. (1960). Pteridophytes of eastern India-I. Enumeration of the species collected and their nomenclature. 
Bulletin of Botanial Survey of India 2: 309-314.

Panigrahi, G. \& R.D. Dixit (1969). Studies in Indian Pteridophytes-2. The family Osmundaceae in India. Journal of the Indian Botanical Society 48: 90-101.

Singh, S. \& G. Panigrahi (2005). Fern \& Fern-allies Arunachal Pradesh-Vol. 2. Botanical Survey of India, Howrah, India.

Tripathi, O.P., H.N. Pandey \& R.S. Tripathi (2008). Effects of human activities on structure and composition of woody species of the Nokrek Biosphere Reserve of Meghalaya, North-east India. Journal of Plant Ecology (Chinese Version). 73-79pp.

Vasudeva, S.M., S.S. Bir \& P. Kachroo (1990). Pteridophytic flora of north-eastern India-3 (Families: Aspleniaceae-Oleandraceae). Indian Fern Journal 7: 66-85.
Author Details: BIKARMA SINGH worked as JRF \& SRF in Botanical Survey of India, Eastern Regional Circle, Shillong under MoEF funded Nokrek project; currently engaged as a plant taxonomist in North-Eastern Hill University, Shillong in projects related to survey of unexplored areas of northeastern India.

V.N. SINGH worked as research associate under MoEF funded Nokrek project in Botanical Survey of India, Shillong.

S.J. PHUKan Ex-Joint Director \& Principal Investigator of the MoEF funded Nokrek Project, Botanical Survey of India, Shillong.

B.K. SINHA currently Joint-Director \& Co-PI of the MoEF funded Nokrek Project, Botanical Survey of India, Shillong.

S.K. BORTHAKUR currently Professor in

Department of Botany, Gauhati University, Assam.

Author Contribution: BS prepared this article under the supervision of the seniors and guides. VNS, SJP, BKS and SKB helped in making this article. 